\title{
Resilience through synergies between agriculture and tourism
}

A comparison of two contrasting trajectories in the Tyrolean Alps

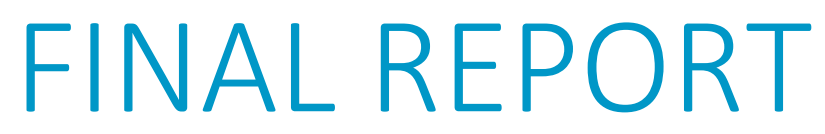

Funding body: Earth System Science, Austrian Academy of Sciences

Rike Stotten ${ }^{1}$, Georg Leitinger ${ }^{2}$, Lisa Huber ${ }^{2}$, Erich Tasser ${ }^{3}$

${ }^{1}$ Department of Sociology, University of Innsbruck, Universitätsstraße 15, 6020 Innsbruck, Austria ${ }^{2}$ Department of Ecology, University of Innsbruck, Sternwartestraße 15, 6020 Innsbruck, Austria

${ }^{3}$ Institute for Alpine Environment, Eurac Research, Viale Druso 1, 39100 Bozen/Bolzano, Italy

ISBN-Online: 978-3-7001-8-8843-8

DOI: $10.1553 /$ ESS-RESULT 


\section{Former and student collaborators}

University of Innsbruck, Department of Sociology:

- Hannes Hermann

- Carolin Holtkamp

- Marius Käfer

University of Innsbruck, Department of Ecology:

- Claudia Gruber

- Peter Holmeier

- Kathryn Marschall

- Ulrike Sulzer

Eurac Research, Bolzano:

- Andreas Altzinger

\section{Acknowledgements}

We wish to thank all our respondents in the Ötztal valley for their time and effort in participating in our research. Indeed, without their help and enthusiasm, this research would not have been possible. Further, the project team would like to thank the Alpine Research Centre Obergurgl and its scientific coordinator Klaus Schallhart. The International Advisory Board of the project also helped by their participation in several debates towards the successful realization of the project. 


\section{SUMMARY}

The tourism industry contributes to the rural livelihood in Austrian mountain areas and traditional, multifunctional farming has various ways to integrate with the tourism sector. Remote mountain communities in the European Alps face however numerous social, economic, and ecological challenges and have undergone substantial socioeconomic changes over the past decades, leading to the decrease of farmland, an overdependence on tourism, and the outmigration of young people.

The RESULT project explores the synergies provided by interlinkages between agriculture and tourism on three different levels: The effects on the resilience of family farms, second of the rural communities and their surrounding social-ecological system, measured by the provision of selected ecosystem services. The project RESULT investigates how to define and operationalize the resilience of mountain regions, communities, and environments.

The empirical case is provided by Obergurgl and Vent, two Alpine villages in the municipality of Sölden in the Upper Ötztal Valley (Tyrol, Austria). They offer a unique opportunity to study the interdependencies between agriculture and tourism over a long period. First, both villages exhibit a long history of tourism. Second, they have chosen two distinctly different development trajectories, one focussing on winter tourism with skiing (Obergurgl) while the other profiles as a mountaineering village (Vent). Third, both were part of a large 'Man and Biosphere' (MAB) project between 1973 and 1979 which studied the structural change from agriculture to tourism.

A mix of qualitative and quantitative sociological and ecological methods, including expert interviews, farm biographies, GIS-mapping, landscape, and ecosystem models have been applied to investigate the different levels of resilience.

The findings highlight that farming and tourism are highly enmeshed and that the additional income creates room for manoeuvre for the farms to activate their adaptive capability. At the same time, peasant values guide farming activities. The farms in this study demonstrate a strong farm resilience that is enabled by farm diversification and rooted in their peasant habitus. Conclusions of the investigation of community resilience reveal that the different trajectories of the Obergurgl and Vent still result in similar economic, structural, and political lock-ins that reinforce path dependencies. The interdisciplinary investigation on social-ecological resilience densified other findings on farm and community resilience as well as on the provision of ecosystem services into a novel framework combining sustainable rural livelihoods and ecosystem service concepts. The final findings have been calculated with a modified Shannon-Wiener Index that revealed a higher social-ecological resilience for the village of Vent than Obergurgl. Regarding the application of different resilience approaches in mountain regions, a comparison of five dimensions characterizing the approaches revealed, that both approaches have strengths and weaknesses, so that an integration is recommended.

Finally, the findings of the project have been spread in science as well as in practice. At the end of the project, a public stakeholder workshop took place to feed back our research findings and to initiate a discussion among community members about how to strengthen the social-ecological resilience. 


\section{ZUSAMMENFASSUNG}

Allgemein trägt die Tourismusindustrie zur Erhaltung der ländlichen Lebensgrundlagen in den österreichischen Berggebieten bei. Die traditionelle, multifunktionale Landwirtschaft hat dabei verschiedene Möglichkeiten, sich in den Tourismussektor zu integrieren. Gleichzeitig stehen die Berggemeinden in den europäischen Alpen jedoch zahlreichen sozialen, wirtschaftlichen und ökologischen Herausforderungen gegenüber und haben in den letzten Jahrzehnten erhebliche sozioökonomische Veränderungen erfahren, die zur Abnahme der landwirtschaftlichen Nutzflächen, eine übermäßige Abhängigkeit vom Tourismus und zur Abwanderung junger Menschen führten.

Das Projekt RESULT untersucht die Synergien, die sich aus der Verknüpfung von Landwirtschaft und Tourismus auf drei verschiedenen Ebenen ergeben: Erstens die Auswirkungen auf die Resilienz von bäuerlichen Familienbetrieben, zweitens die der ländlichen Gemeinschaften und auf das sie umgebende sozial-ökologische System, gemessen an der Bereitstellung ausgewählter Ökosystemleistungen. Darüber hinaus untersucht das RESULT-Projekt, wie die Resilienz von Bergregionen, Gemeinschaften und deren natürlichen Umgebungen definiert und operationalisiert werden kann.

Auf empirischer Ebene werden Obergurgl und Vent, zwei Alpendörfer in der Gemeinde Sölden im hinteren Ötztal (Tirol, Österreich) untersucht. Sie bieten eine einzigartige Gelegenheit, die wechselseitige Abhängigkeit von Landwirtschaft und Tourismus über einen langen Zeitraum zu untersuchen. Erstens weisen beide Dörfer eine lange Geschichte des Tourismus auf. Zweitens haben sie zwei deutlich unterschiedliche Entwicklungspfade gewählt, wobei der eine auf den Wintertourismus mit Skifahren (Obergurgl) und der andere als Bergsteigerdorf (Vent) ausgerichtet ist. Drittens waren beide Teil des "Man and Biosphere"-Projekts (MAB) zwischen 1973 und 1979, das den Strukturwandel von der Landwirtschaft zum Tourismus untersuchte. Ein Mix aus qualitativen und quantitativen soziologischen und ökologischen Methoden, darunter ExpertInnenbefragungen, Biographien von Landwirtschaftsbetrieben, GIS-Kartierungen, Landschafts- und Ökosystemmodelle wurde angewandt, um die verschiedenen Ebenen der Resilienz zu untersuchen.

Die Ergebnisse verdeutlichen, dass Landwirtschaft und Tourismus eng miteinander verflochten. Das Zusatzeinkommen schafft für die bäuerlichen Betriebe finanziellen Spielraum zur Anpassung an sich ändernde Bedingungen. Gleichzeitig leiten bäuerliche Werte die landwirtschaftlichen Aktivitäten. Die bäuerlichen Betriebe in dieser Studie zeigen eine starke landwirtschaftliche Resilienz, die durch die Diversifizierung der Betriebe ermöglicht wird und in ihrem bäuerlichen Habitus verwurzelt ist. Die Schlussfolgerungen der Untersuchung der Resilienz der dörflichen Gemeinschaften zeigen, dass die unterschiedlichen Entwicklungspfade von Obergurgl und Vent dennoch zu ähnlichen wirtschaftlichen, strukturellen und politischen Lock-In Effekten führen und die Pfadabhängigkeiten verstärken. Abschließend verdichtete die interdisziplinäre Untersuchung der sozial-ökologischen Resilienz die Erkenntnisse über die Resilienz von bäuerlichen Betrieben und Gemeinschaften sowie über die Bereitstellung von Ökosystemleistungen zu einem neuartigen Konzept, das die Konzepte der "sustainable rural livelihood" und "Ökosystemleistungen" kombiniert. Die endgültigen Ergebnisse wurden mit einem modifizierten Shannon-Wiener-Index berechnet, der für das Dorf Vent eine höhere sozial-ökologische Resilienz ergab als für Obergurgl. Hinsichtlich der Anwendung unterschiedlicher Resilienzkonzepte in Bergregionen ergab ein Vergleich von verschiedenen Dimensionen, dass beide Konzepte Stärken und Schwächen aufweisen, so dass eine Integration empfohlen wird.

Abschließend wurden die Erkenntnisse des Projekts sowohl in der Wissenschaft als auch in der Praxis verbreitet. Beispielsweise fand ein öffentlicher Workshop mit Entscheidungsträgern beider Dörfer statt, um unsere Forschungsergebnisse zu verbreiten und eine Diskussion unter der Bevölkerung der beiden Dörfer darüber anzustoßen, wie die sozial-ökologische Resilienz gestärkt werden kann. 


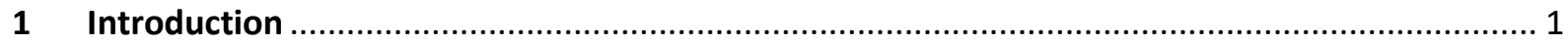

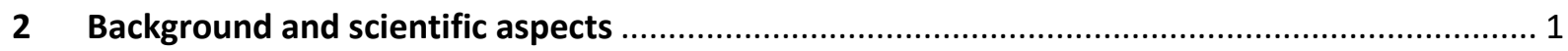

2.1 Trends in agricultural development ........................................................................... 1

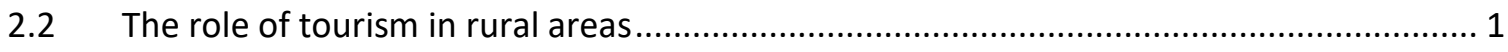

2.3 Interlinkages of the two economic activities .................................................................. 2

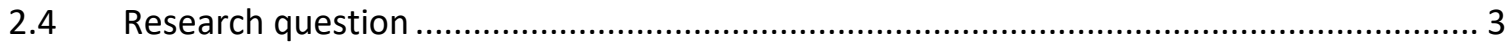

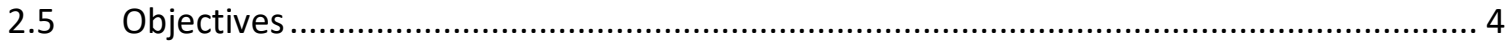

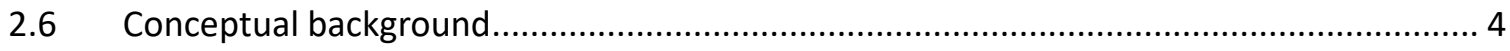

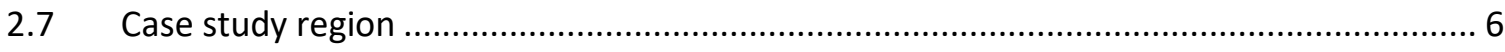

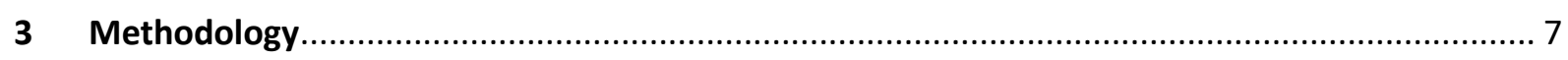

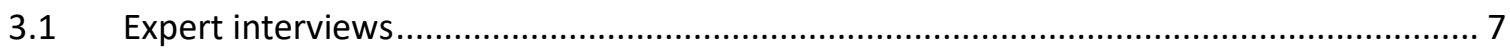

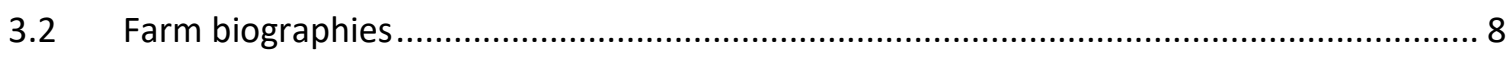

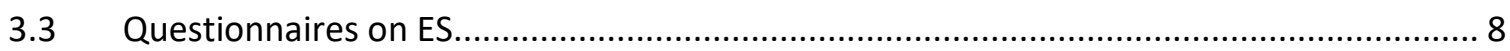

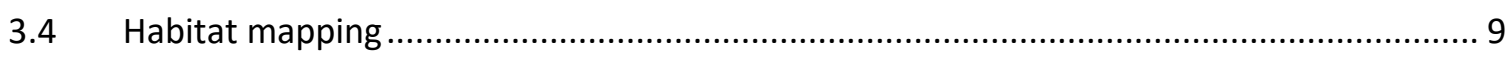

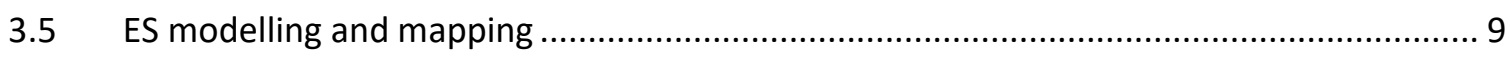

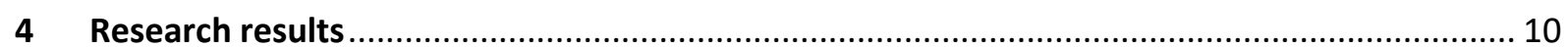

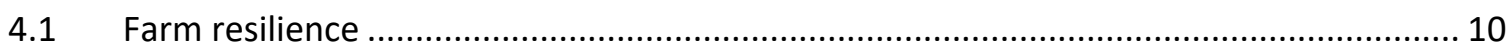

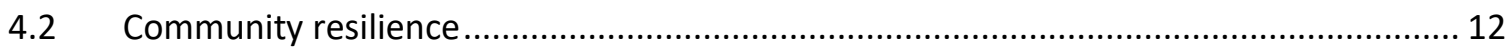

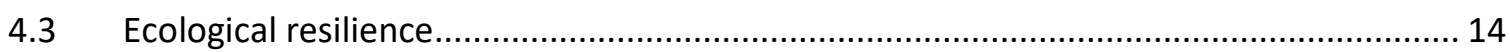

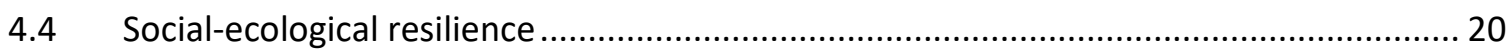

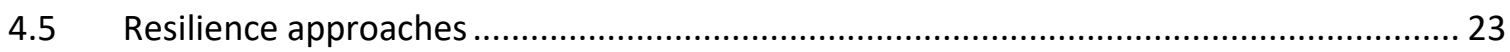

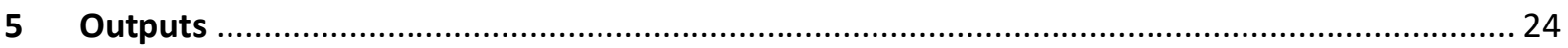

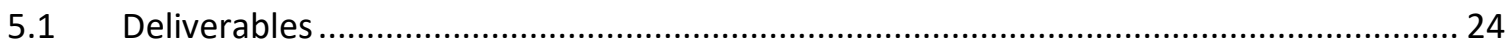

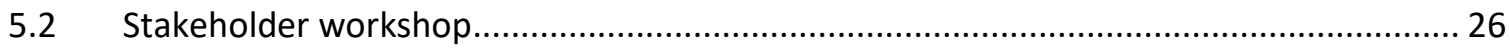

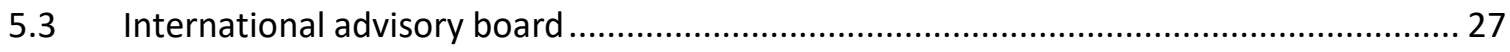

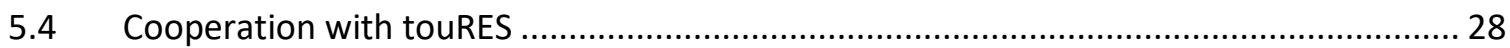

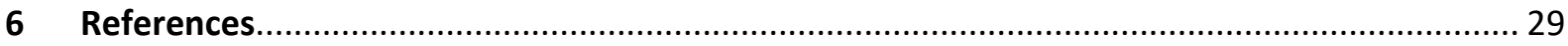

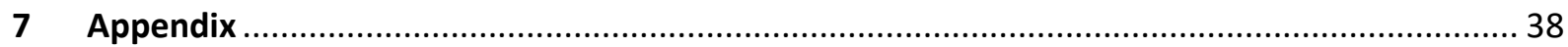


This interdisciplinary project investigated the consequences for resilience of the interaction between agriculture and the tourism industry in mountain areas. We examined how synergies between agriculture and tourism contribute to the resilience of family farms as well as of the community in general, and how they impact on ecological resilience (i.e. on the provision of ecosystem services).

First, we will outline the contextual and conceptual frame and the research questions of the project proposal. Then we will present our methods and results. Finally, we provide information on the output of the project, such as publications and workshops.

\section{$2 \quad$ Background and scientific aspects}

More than $30 \%$ of the European Alps is used for agriculture, either as farmland or natural and seminatural grassland. Even if the share of the population active in farming has shrunk dramatically with structural change, agriculture remains the main preserver of a cultural landscape required for recreational and touristic uses. Agriculture in Europe, especially in mountain regions, has turned from monofunctionality focusing on food production towards multi-functionality (Flury et al. 2013). In addition to food production, its function for leisure, recreation and tourism as well as other economic activities affect the maintenance of vital rural areas. At the same time, the decline in the importance of agricultural production stimulates, not to say forces, farmers to adapt their farm management. From this arise new options to diversify farming structures and to generate additional income (Markantoni et al. 2014).

\subsection{Trends in agricultural development}

The relations between agriculture and rural development are complex (Lobao and Sharp 2014). While traditionally farming was often seen as a leading sector for economic development, today rural is not automatically agricultural anymore, however, it would be nothing without the agricultural side (Van Der Ploeg, Jan Douwe et al. 2000).

With the shift from productivism to post-productivism, which means, from maximizing food production quantity towards sustainable, quality farming (Wilson 2001), the income earned from food production is falling in (European) developed countries. Recently, a transition has set in to neo-productivism in the sense of "'re-positioning' of farming to be central for broader aspects of sustainable rural development" (Burton and Wilson 2012). Compensations for the provision of ecosystem services balance the loss in income. In addition, off-farm employment is on the rise to support farm income, especially on small farms (Weiss 1994). Combinations with tourism in all its forms are an important way of agricultural diversification to battle the cost-price squeeze and to cope with income fluctuations from food production (Markantoni et al. 2014).

\subsection{The role of tourism in rural areas}

Tourism is broadly perceived as an economic tool for regional development, especially in remote areas where other economic investment is difficult. Even if the purpose of regional development varies, the main objective is to increase employment, technology and development within a certain area. To give a simple definition of rural tourism, it "is tourism which takes place in the countryside" (OECD 1994). Even if the phenomenon of rural tourism is not new, a growing number of tourists has marked a new 
rural tourism since the 1970s (OECD 1994). Those rising numbers contributed to the transformation of villages and rural society. Tourism industry as a labour-intensive sector often mainly creates a number of low paid, seasonal jobs and less qualified employment opportunities. However, the economic activity in tourism also impacts on the employment pattern of other labour sectors in a region through the creation of enterprises and jobs and, with it, income (Telfer 2015; Mitchell and Hall 2005; Hall and Page 2006).

Concerning the effects on structural development, George et al. (2009; Hall and Page 2006) state that tourism in rural areas primarily offers an opportunity for conservation and sustainability to keep the rural character of an area, rather than being an urbanizing and development tool. Further, the integration of agriculture into tourism is just one facet of rural tourism; there are also rural areas not based on farming with a well developed tourism industry.

\subsection{Interlinkages of the two economic activities}

With the sinking importance of food production, in particular in mountain areas, farm diversification became more important. Multifunctional farming systems provide supplementary products and services, which support a diversified rural economy, which is consequently less vulnerable (López-i-Gelats 2013). Especially in the Alpine Arc, tourism contributes significantly to rural livelihoods. In some areas, as in the Stubai valley south of Innsbruck, income opportunities for farmers in tourism stabilize the farming structure, absorb short-term shocks and slow down farm abandonment. Contrary, in Norway (Oppdal) farm work in tourism seems to encourage farm decline, being economically more attractive than farming (Schermer et al. 2016). Although Richard Sharpley and Adrian Vass (Sharpley and Vass 2006) argue that literature often refers to diversification into tourism as counteracting socioeconomic problems of rural areas and particularly farming, the OECD (1994) argues that agritourism will not generally save the farming society.

On the whole, the tourism industry provides five options to integrate farm activities. First, farms provide services like "holidays on farms" for tourists. As one third of all farms in Tyrol offer this service, it constitutes an important pillar of agriculture (Meixner 2006; Meixner et al. 2010). Agritourism does not just include farmer-based accommodation, but also farm-based meals ${ }^{1}$, farm-based activities and events, as well as the sale of farm products (Che et al. 2005). The transition from a resource-based economy to a service-oriented industry demands very different skills (George et al. 2009) and further opens up a family farm into an enterprise accessible to the public (Bianchi 2011). A further source of income is off-farm employment in tourism. As winter is a slack period for farming and winter tourism is the backbone of tourism in Austria and especially in Tyrol (Meixner et al. 2010), employment in tourism is synergetic in labour demand. Farmers often work in mountain rescue services, slope grooming and ski lift services, as ski instructors or other tourism-related activities (show dairy, ...). But in summer, too, they act as mountain and hiking guides as well as in alpine pasture tourism with hospitality service. A third potential synergy is the provision of high-quality food products for the hospitality sector and for tourists within the region. In this way, relations between food producer and food consumer are built up and potential clients for farmers' markets or farm-based food festivals can be won (Sidali et al. 2013). Although supplying the local hospitality sector has been on the agenda of agricultural advisory services for a long time (Schermer 1989), results to date are limited. In contrast, rationalization in restaurants and rising hygienic requirements as well as food safety regulations have even

\footnotetext{
${ }^{1}$ Due to legal constraints to a lesser extent in Austria.
} 
resulted in a decline of local product relations. A fourth contribution of tourism is the increased awareness of the landscape maintenance function of agriculture and the cultural ecosystem services (like aesthetics) provided by farming. This is a major justification for public transfer payments and may translate into direct payments for farmers at municipal level, as tourism areas are rather affluent. Finally, as most of the touristic activities, like Alpine or Nordic skiing, take place on farmland, tourism associations or ski lift operators have to pay compensation for the right to use ski slopes or crosscountry skiing trails over farmland.

The resulting symbiosis of agriculture/farming and tourism is generally expected to stabilize the ongoing structural change in rural areas (Fleischer and Tchetchik 2005; Meixner 2006; Meixner et al. 2010; Schermer et al. 2016) and to create public awareness for the values of farming in general (Tew and Barbieri 2012). Moreover, the direct contact with tourists as customers of landscape provides a positive feedback. Thus the integration of tourism and agriculture increases added value and appreciation for farming at the same time. While this is a general claim, there is so far little scientific evidence whether these mechanisms work together in the long term and if so, how they do.

The interaction of tourism and agriculture as described above may also provide a basis for regional economic circuits and social networks, which strengthen community resilience against negative influences. Moreover, a viable farming community contributes significantly to the provision of ecosystem services and the social-ecological resilience of the landscape (i.e. social-ecological system (SES)). Ecosystem services form an important asset base for the livelihoods in rural areas (Power 2010). Given various definitions of the term 'ecosystem service (ES)', we need to define it for our study: ecosystem services (ES) are 'beneficial flows arising from natural (environmental) capital stocks and fulfilling human needs' (Dominati et al. 2010). Generally, we distinguish four types of ES: provisioning services, including all products we obtain from an ecosystem; regulating services, which include benefits from the regulation of ecosystem processes; cultural services, focusing on the immaterial aspects, and supporting services, which are needed to provide all other ES (Hassan et al. 2005).

\subsection{Research question}

Building on this, the project aims to find out whether and how the interaction of agriculture and tourism may sustain and increase resilience in the long term.

We investigate resilience on three levels:

1. First, the project addresses the resilience of the selected farms and investigates how different forms of integration into tourism may contribute to make family farming more resilient to shocks and for survival in general.

2. A second focus is laid on community resilience, shifting from the perspective of the individual farm to the surrounding socioeconomic context. The project will investigate how different trajectories of tourism development in relation to the integration of farming impact on community resilience.

3. Finally, farm resilience and community resilience are closely intertwined with ecological resilience, understood here as the provision of ES which form a basis for local livelihoods and economic activities. The project combines socioeconomic research with ecologic research to investigate more thoroughly the resilience of the social-ecological system.

For the cooperation with the touRES project (see chapter 5.4) we integrated a fourth research question in our work: 
4. How to define, operationalize and assess the resilience of mountain regions, communities and environments?

\subsection{Objectives}

Scientifically, the objective of the project is to develop an interdisciplinary approach based on natural and social sciences to investigate interlinkages of farming and tourism. The study identifies the impact of these interlinkages on social-ecological farm and community resilience that form the base for the long-term development of landscape preservation and the provision of ES. We model the provision of ES historically and currently to quantify the impact of the synergies of agriculture and tourism on different social- ecological systems. In practical terms, the project provides deeper insights into the interlinkages between farming and tourism industry in rural areas. Detailed knowledge of the synergies may improve agricultural support programmes as well as rural development strategies and help to maintain and increase social-ecological resilience on a farm and community level.

\subsection{Conceptual background}

The project uses the concept of social-ecological resilience. Brian Walker et al. (2004) define resilience as "the capacity of a system to absorb disturbance and reorganize while undergoing change so as to still retain essentially the same function, structure, identity, and feedbacks". While initially developed by ecologists, it is now widely used to study how the interaction between social and ecological subsystems induces and drives changes (Adger 2000; Folke 2006; Davidson 2010; Rickards and Howden 2012). The concept of social-ecological resilience builds on an understanding of ecosystems as dynamic and evolving under the influence of external social and economic forces. Moreover, a system is understood as embedded in hierarchies, with slow and fast changes on larger and smaller scales (Holling 2001). This helps structuring the assessment of faster and slower drivers of change on different spatial scales.

Resilience at farm level is examined in terms of economic, social and natural capital on specific farms. Not just the natural capital, although the biophysical structures of the farmland do influence vulnerability, but also economic (financial) capital and especially social capital have an impact. From a social perspective, resilience considers not just the actions of the farmers, but also includes the wider social context (policies, norms and power relations) (Darnhofer et al. 2016). Applying resilience thinking to agriculture, Ika Darnhofer (2014) distinguishes three capabilities that characterize resilient farms: the ability to buffer shocks, the ability to adapt through implementing marginal changes, and the ability to transform through implementing radical change. Indeed, while in literature on ecosystems the focus is often on maintaining an ecosystem within thresholds, in social systems adaptability and transformability arguably play a more important role. Thus, while farms need to be able to buffer or absorb shocks in the short term (e.g. after an extreme weather event or a sudden spike in prices), over the medium and longer term, they also need to be able to adapt or even transform.

At community level, the concept of rural community resilience by Wilson (2012b, 2010) serves as a framework to investigate the vulnerability and/or the resilience of communities as they react to transitional ruptures. A transitional rupture or a shock, such as a natural or human disaster, demands a reorganization of structures for recovery. A mix of well developed economic, social and natural capital is important for a resilient community. 
Social-ecological resilience is measured in this project by the provision of certain ES. This includes (1) the identification, selection and weighting of relevant ES, and (2) modelling as well as finally mapping ES. Both steps are a prerequisite for comparing landscapes by their 'ES-performance'.

Using participatory approaches with stakeholders/key informants to identify beneficiaries and weight ES types by their importance allows a comprehensive evaluation of bundles of ES. Modelling and mapping of ES on the landscape scale require ES models following either land use/land cover (LULC) or functional traits (i.e. diversity). LULC-based ES models assign values for ES provision to specific LULC types using experimental data on ES provision (Schirpke et al. 2013a). Functional trait-based modelling works at species or functional group level and links ES provision directly to functional traits of biotic and abiotic factors via empirical models (Lavorel et al. 2011). While the LULC-based modelling approach has fewer data requirements and allows the implementation of several modelling techniques for specific ecosystem processes or services, trait-based models offers the incorporation of dynamics of functional traits (i.e. species composition). This is essential when modelling over large time scales and significant changes in vegetation composition as a result of changes in management intensity or climate. Although commonly accepted, we are not aware of a research project using both approaches in the methodological portfolio of involved project partners.

To combine social-economic perspectives of resilience with ecological resilience, the project applies an adapted framework of sustainable rural livelihoods (Scoones 2009, 1998) (see Figure 1). The vulnerability context against which the resilience is assessed is characterized by trends and by sudden shocks and extreme events. Therefore the project establishes statistical time series in a longitudinal study to be able to monitor the adaptation to changes which materialize in long-term trends (demographic, economic, ecological etc.) over the entire period from 1980 to the present. The change in natural capital and resource flows (i.e. ES) is driven by both management decisions (i.e. change in land-use intensities) and climate change. To differentiate the impact of land-use/cover change (LULC) and climate change (CC) on agriculture and tourism, the long-term trends of selected ES are investigated.

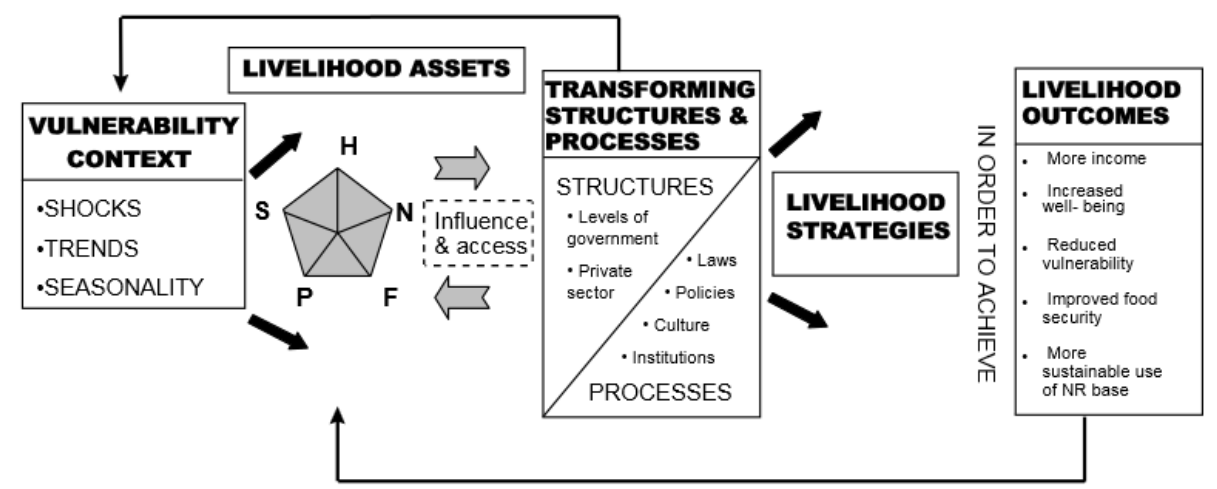

H Human capital: skills, knowledge, ability to work, good health, needed to pursue livelihood strategies;

P Physical capital: basic infrastructure (transport, accommodation, water, energy, communications), production equipment and means to pursue livelihoods;

S Social capital: social resources (networks, memberships, relations of trust, access to general social institutions) to draw on in pursuit of livelihoods;

F Financial capital: financial resources (savings, credit, regular remittances or pensions) that offer different livelihood options;

N Natural capital: natural and environmental resources (land, water, wildlife, biodiversity) needed to pursue livelihoods.

Figure 1: Sustainable rural livelihoods framework (Carney et al. 1999).

In addition to this longitudinal study, the project identifies certain points of major ruptures within the last 35 years: extreme events like natural disasters or changing framework conditions (e.g. the flooding of 1987 or Austria accession to the EU in 1995). The project takes a closer look at farm and community 
level at the assets and capabilities available to deal with shocks in these critical situations. These transversal examinations investigate (1) which strategies farms and communities have developed to deal with trends and to mitigate shocks and (2) if/how ES provision has changed. An institutional analysis focuses on the structures and processes which guide the development of strategies at individual and communal level.

The livelihood outcomes are described in terms of individual farm resilience, community resilience and ecological resilience as indicated by the change in the provision of ES.

\subsection{Case study region}

The case study region lies in the Ötztal valley in the southwest of the Austrian province of Tyrol (Figure 2). Administratively Obergurgl and Vent belong to the municipality of Sölden and provide a unique opportunity to study the interdependencies between tourism and agriculture over a long period. First, the two Alpine villages have a long history of touristic development from the late $19^{\text {th }}$ century onwards (Hess 1894). Second, their development trajectories differ greatly, although in both cases based on tourism. Obergurgl focuses almost entirely on winter tourism. Because of restrictions of a nature reserve and steep hillsides, Vent has positioned itself as a mountaineering village, with a stronger focus on the summer season. Third, detailed studies of the process of structural change from an agricultural society to a modern service society were carried out between 1973 and 1979 within a large MAB project (Meleghy et al. 1980; Preglau et al. 1985), resulting in a comprehensive collection of quantitative and qualitative data. This provides a baseline survey against which changes may be measured. While the project assessed a broad range of indicators monitoring social change, we want to concentrate on the contribution of tourism to the social-ecological resilience of the farming system and thus in turn on the social-ecological resilience of the communities and the provision of related ES.

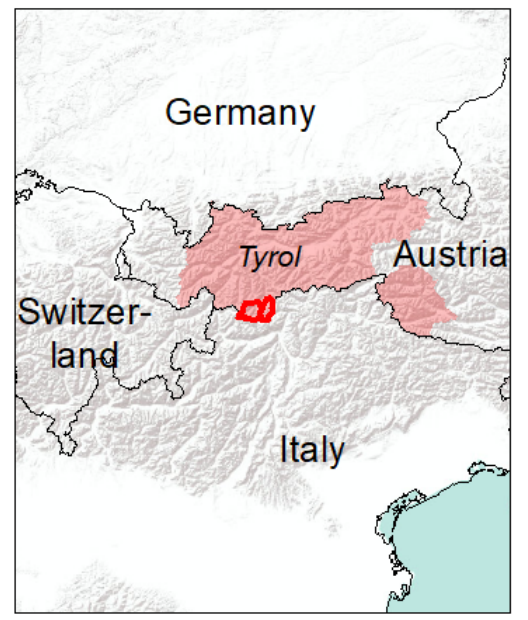

: ski area 2011

MIIUCN protected area 2015 Sources: Esri, USGS, NOAA

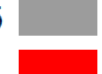

Glacier Little or no vegetation Settlement Shrub

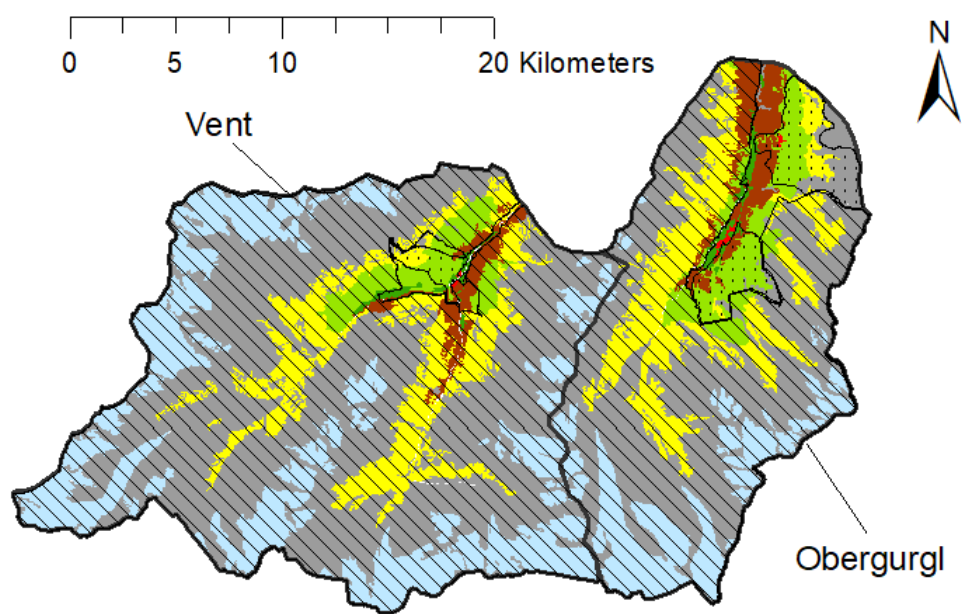

Unused grassland Grassland of high land-use intensity Grassland of low land-use intensity

Figure 2: Overview of case study sites, land use and land cover as of 2015 (Huber et al. 2020). 
The upper Ötztal valley leading to Obergurgl (1927 m a.s.l.) with its population of more than 500 people (STATISTIK AUSTRIA 2017) has gentler slopes than in the lateral valley of the Ötztal, where Vent is located. At the end of the $18^{\text {th }}$ century, both villages were typical Alpine agrarian communities and their economy was based on animal husbandry (no arable land). In Obergurgl, the 200 inhabitants were mainly engaged in subsistence farming. However, the population decreased as food shortage forced migration. A modernization process in the course of developing tourism in the Alps initiated an economic recovery in the village (Meleghy et al. 1985; Preglau et al. 1985). Because of the location in a wide valley, Obergurgl benefitted from the rise of mass tourism in the Alps in the $20^{\text {th }}$ century to develop ski lifts and slopes. Today the village is an internationally recognized skiing destination and economically depends on winter tourism with more than 4,000 guest beds and 56 kilometres of pistes (Footprints 2008, 2007). Consequently, farming activities decreased, but still provide the base for tourism as the scenic beauty of the village is attributed to the traditionally farmed landscape. And even if cultivation is labour intensive and time consuming, there is hardly any fallow land within the valley (Pinzer and Pinzer 1998).

Vent (1900 $\mathrm{m}$ a.s.I.) is located in a lateral valley of the Ötztal that is very narrow and flanked by steep slopes. The Alpine village has a population of nearly 150 (STATISTIK AUSTRIA 2017). Farming in Vent was traditionally also based on animal husbandry. Tourism started early in the village, as the glacial ice lake Vernagtsee attracted scientists as well as curious individuals. Contrary to Obergurgl, the local population refused an intensive exploitation of the landscape in favour of tourism (Pinzer and Pinzer 1998). The skiing facilities in Vent are relatively small. Vent is today a classified as a 'mountaineering village', approved by several Alpine institutions, with a focus on 'gentle tourism'. It guarantees professional tourist offerings for mountaineers, but at the same time respects the excellent landscape and environmental quality. Vent is committed to the preservation of local cultural and natural values (Mountain Villages).

\section{Methodology \\ 3.1 Expert interviews}

To draw an image of economic, social, cultural, political and natural capital in each village, we conducted several expert interviews. These are usually of an open structure to gain a broad range of information and knowledge and to access the expert's tacit knowledge (Bogner et al. 2014). In total, we conducted 20 interviews (see Table 1) with local actors from both villages as well as with regional stakeholders. These lasted between 30-100 minutes and were held between October 2017 and June 2018. Among the local interviewees, we considered both genders, different age groups as well as immigrants. A verbatim transcript of the expert interviews served to transform spoken material into a written form. In this process, data were anonymized. For data evaluation, we applied a qualitative content analysis (Mayring 2007). This systematic, rule-guided and theoretically grounded step-by-step approach to qualitative text analysis is based on the inductive development of categories close to the given text material and the application of deductive verification of those categories in terms of the research questions and theory. ATLAS.ti software was used to organize and code the text material in order to develop the categories (Konopásek 2011). Finally, 52 inductively developed categories were deductively grouped into the five domains of the community resilience concept (see Chapter 4.2). The knowledge gained was enriched by document analysis of development concepts and laws. 
Table 1: Stakeholders selected for expert interviews.

\begin{tabular}{|l|c|c|c|}
\hline Interviewees (double occupation) & Vent & Obergurgl & Regional \\
\hline Farmer & 2 & 2 & \\
\hline Provider accommodation & 6 & 6 & \\
\hline Manager lift company & 1 & 1 & \\
\hline Local business & & 1 & \\
\hline Member of municipal council & 2 & 3 & \\
\hline Mayor & & & 1 \\
\hline Local historian & & & 1 \\
\hline Manager nature park & & & 1 \\
\hline Scientist from the MAB study & & & 1 \\
\hline
\end{tabular}

\subsection{Farm biographies}

To obtain information about farm resilience, we conducted narrative or biographical interviews (Küsters 2009) with farmers, called farm biographies for this study. The purpose of such interviews is to enable the participant to narrate their experiences around the study theme (Allen 2017). With an introductory question designed to generate a narrative, the interviewer stimulates the participant to express his or her orientation patterns through descriptions (Küsters 2009).

The focus of this study is on the 'biography' of the farm rather than on that of the farmer. Farms were selected from a list of registered farm managers (all male) suggested during previous expert interviews. Additional farmers, whose names had been suggested during other farm biographies, were contacted for interviews (snowball method of sampling (Przyborski and Wohlrab-Sahr 2009). The opening question asked for a narration on the farm development, especially during the last 40-50 years. Thereupon, immanent questions were posed. Questions on aspects of resilience, such as (additional) income, investments, participation in local cultural associations, and change in land use, had been prepared as exmanent issues of interest. A timeline on carton from the 1970s on helped the farmers to express and accentuate specific moments for their farm, which were noted directly on paper arrows during the interview. This helped the farmers to visualize the development of the farm and reflect more deeply on it. In total, nine interviews were conducted (5 in Obergurgl, 4 in Vent, see Table 1). The farm biographies with the farmers were done between November 2017 and June 2018 at their farms and lasted between 30 and 90 minutes.

Anonymized verbatim transcripts served to analyse the data and reapplying a qualitative content analysis (see Chapter 3.1). In total, six categories were developed: farm diversification, disturbances, buffering, adaptation, and transformation strategies, as well as habitus.

\subsection{Questionnaires on ES}

Questionnaires were distributed to inhabitants of the villages Obergurgl and Vent in order to find out about people's perception of the actual contribution of the local landscape to certain ecosystem services and their importance for the villages. For this, 14 ecosystem services were preselected with expert knowledge: water provision, food production, animal feed production, raw materials, energy, natural hazards regulation, biodiversity, pollination, habitats for animals, humans and plants, climate regulation, recreation, aesthetic value, air quality and preservation of traditional local livestock breeds. They were explained and the interviewees were asked to rate them from 1 (not important) to 4 (very important). In the period from March to August 2018, the questionnaires (Paier 2010) were distributed in person in Vent and Obergurgl. Special care was taken to select only people with good local 
knowledge for the survey, ideally long-term residents. In Obergurgl in particular, this was not an easy task as many of the people employed in the hospitality businesses are seasonal workers who often have insufficient knowledge of the area and were therefore excluded from the study. In total, 40 individuals ( $27 \%$ of all locals) were interviewed in Vent and $66(13 \%)$ in Obergurgl.

\subsection{Habitat mapping}

As many of the ES models are based on land-use/land-cover maps, we first mapped habitats for the case study site for several historical dates, i.e., 1860, 1950, 1970, 2000 and 2015. For each time step, historical maps and orthophotos were analysed following a methodical approach for standardized landscape studies in small dimensions (Tasser et al. 2009). The Francisco-Josephinian Cartographical Register from 1860 marks the start of spatially explicit historical LULC. It mapped different LULC types (e.g. forest, meadows, pastures, settlements) as well as specific landscape features (e.g. rivers, rocks). For the years 1950 and 1970, we used georectified aerial photographs and for the years 2000 and 2015 we consulted orthophotos. All data were mapped and referenced in a Geographic Information System, where only areas greater than four hectares were considered. To corroborate the land-cover maps, free response interviews with farmers were conducted.

\subsection{ES modelling and mapping}

Six essential ES (two provisioning, two regulating \& maintaining and two cultural; Table 2) were selected and quantified for five historical time steps (1860, 1950, 1970, 2000, 2015).

Table 2: Ecosystem service (ES) indicators modelled in this study and references for modelling techniques and data. ES are categorized after the Common International Classification of Ecosystem Services (CICES) (Haines-Young and Potschin 2018).

\begin{tabular}{|c|c|c|c|}
\hline $\begin{array}{l}\text { Ecosystem service } \\
\text { (category) }\end{array}$ & Indicator & Analyses after & Data sources \\
\hline $\begin{array}{l}\text { Fodder production } \\
\text { (provisioning) }\end{array}$ & Annual forage production & $\begin{array}{l}\text { (Egger et al. 2004; } \\
\text { Schirpke et al. 2013b) }\end{array}$ & $\begin{array}{l}\text { habitat maps* (Sulzer 2018); } \\
\text { digital elevation model (DEM), Tyrolean } \\
\text { Information System (tiris (C Land Tirol) }\end{array}$ \\
\hline $\begin{array}{lr}\text { Water } & \text { provision } \\
\text { without } & \text { glacier } \\
\text { runoff } & \text { (provision- } \\
\text { ing) } & \end{array}$ & $\begin{array}{l}\text { Runoff for the vegetation period } \\
\text { (May-September) }\end{array}$ & (Schirpke 2011) & $\begin{array}{l}\text { habitat maps* (Sulzer 2018); } \\
\text { digital elevation model (DEM), Tyrolean } \\
\text { Information System (tiris (C) Land Tirol); } \\
\text { precipitation (Fick und Hijmans 2017); } \\
\text { evapotranspiration per habitat (Fecht et } \\
\text { al. 2005; Wieser et al. 2008) }\end{array}$ \\
\hline $\begin{array}{l}\text { Plant diversity (reg- } \\
\text { ulating \& maintain- } \\
\text { ing) }\end{array}$ & $\begin{array}{l}\text { Area-weighted mean species } \\
\text { richness of vascular plants }\end{array}$ & (Tasser et al. 2008) & $\begin{array}{l}\text { habitat maps* (Sulzer } 2018 \text { ); } \\
\text { mean species number per habitat (Tasser } \\
\text { et al. 2008) }\end{array}$ \\
\hline $\begin{array}{l}\text { Natural hazards } \\
\text { regulation (regulat- } \\
\text { ing \& maintaining) }\end{array}$ & $\begin{array}{l}\text { Protective forest for ava- } \\
\text { lanches, rock fall and channel } \\
\text { processes }\end{array}$ & $\begin{array}{l}\text { (Klebinder et al. 2009; } \\
\text { Bauerhansl et al. } \\
\text { 2010; Berger et al. } \\
\text { 2012; Voigt 2013) }\end{array}$ & $\begin{array}{l}\text { habitat maps* (Sulzer 2018); } \\
\text { EU DEM v1.0 (European Environment } \\
\text { Agency 2016c); } \\
\text { EU-Hydro (European Environment Agency } \\
\text { 2016b) }\end{array}$ \\
\hline
\end{tabular}


Aesthetic value Landscape beauty (cultural)

Recreation tural)
(Schirpke et al. 2019)

(Schirpke et al. 2018)

Recreation potential (based naturalness, protected areas, landscape composition, type of relief, mountain peaks and accessibility) habitat maps* (Sulzer 2018);

digital elevation model (DEM), Tyrolean Information System (tiris, (C) Land Tirol); Shuttle Radar Topography Mission (SRTM); (Jarvis et al. 2008);

CORINE Land Cover (CLC) 2012 version 18.5.1 (European Environment Agency 2016a);

roads and paths (Schirpke et al. 2019)

habitat maps* (Sulzer 2018);

Natura 2000 database (European Environment Agency 2015b);

Common Database on Designated Areas (CDDA) (European Environment Agency 2015a);

digital elevation model (DEM), Tyrolean Information System (tiris, (C) Land Tirol); roads and paths (Schirpke et al. 2019)

\footnotetext{
* habitat maps include 25 habitat types, see 3.4 .
}

\section{$4 \quad$ Research results}

Below we present our scientific outputs (summaries of published / submitted papers as well as unpublished work) along the three research question presented above.

\subsection{Farm resilience}

First the project addressed the resilience of the farms involved and investigated how different forms of integration of farms into tourism may contribute to make family farming more resilient to shocks and for survival in general.

The role of farm diversification and peasant habitus for farm resilience in mountain areas: the case of the Ötztal valley, Austria (Stotten 2020a)

\section{Background, gap, and research questions:}

Mountain farming, and family farming in particular, has to cope with multiple external pressures that put its existence at risk (Flury et al. 2013). At the same time, farms contribute significantly to the socialecological resilience of rural areas (Renting et al. 2008). In Austria, mountain farming and tourism are highly interconnected as farms generate additional incomes from tourism activities (Anthopoulou and Melissourgos 2013). For the whole of Austria, 11\% of guest beds were provided by farms in 2010 (Ministry of Sustainability and Tourism 2019), and in Tyrol, one-third of all farms offer accommodation services (Meixner 2006). In addition, tourism provides off-farm employment for farmers and a direct market for high-quality food. It increases awareness of the farm's service of landscape maintenance and actors in tourism compensate farmers for the touristic use of farmland (Arriaza et al. 2004). The article analyses how farm diversification into tourism enables family farms to activate different farm resilience capabilities; and the role of the peasant habitus for the resilience of family farms.

\section{Theoretical concepts:}

Family farming has been described as "peasant farming" to emphasize its role as a counter model to industrial or entrepreneurial farming. The peasant habitus is an intrinsic system of dispositions that gives meaning to the practices and structures involved in family farming. One important asset is working the land and autonomy about farming practices (Van Der Ploeg 2009). Farming resilience is defined 
as the capability to absorb shocks and turbulences with buffering strategies and to adapt the farming system proactively to changing conditions (Darnhofer 2014). If a farm has to transform into a completely new system, it is considered not resilient.

Cases and Methodology: see Chapters 2.7 and 3.2

\section{Discussion and conclusion:}

In terms of the first question, results show that additional income generated by farm diversification into tourism decouples farms largely from shocks at the global or national level. Most importantly, farms rely on adaption strategies for survival. The dominating resilience strategy of all interviewed farms is the integration of farming and tourism (accommodation services). Interestingly, most farms would be able to transform their farm into a purely tourism provider since their income mostly comes from tourism, but only one farm did. In Obergurgl, some farms make use of the value of the farmland, which is in great demand for tourism infrastructure development. In Vent, farms rely on direct marketing of their products to the local tourism sector. Concerning the second question, results reveal that all interviewees regard themselves as peasants and they focus on production for themselves, the wider family, or on their tourism activity. The social networks are stronger within the community of Vent than in Obergurgl because direct marketing strategies heavily rely on these networks. Famers don't give up farming because they feel a strong connection with peasant culture and the community. Income from tourism activities often cross-subsidizes agricultural activities. In conclusion, the peasant habitus positively influences the resilience of the farm and it prevents farmers from transforming their farm into a full tourism provider. This would weaken the peasant community, even if the farmland were taken over and worked by other farms. In the end, the peasant habitus activates the resilience strategies of the farm and also strengthens the social-ecological resilience of the region.

Different Forms of Accommodation in Agritourism: The Role of Decoupled Farmer-Based Accommodation in the Ötztal Valley (Austria) (Stotten et al. 2019)

\section{Background, gap, and research questions:}

The general decline of mountain farming all over Europe encourages farmers to adapt their farm management and to diversify their activities into tourism (Weiß et al. 2016). Here, tourism contributes substantially to rural livelihoods and the symbiosis of farming and tourism generally stabilizes the ongoing structural change in rural areas (Fleischer and Tchetchik 2005; Schermer et al. 2016). Studies investigating the effects of agritourism tend to focus on farms where agricultural production is still relevant and the agricultural setting is used to market their accommodation services (Flanigan et al. 2014; Phillip et al. 2010). Our aim was to investigate the impact of different types of farmer-based provision of accommodation on the preservation of the farm and the identification of farmers with farming activities. The following questions where examined: Which forms of farmer-based accommodation occur in a tourism-intensive mountain valley? How do different forms of farmer-based accommodation contribute to total farm income and farm survival in less favoured areas? What is the difference in farmers' identity between the decoupled and the coupled type?

\section{Theoretical concepts:}

Even if various studies have elaborated on a typology of agritourism, a holistic definition of agritourism is missing (Flanigan et al. 2014). Farmer-based accommodation, in the sense of what Streifeneder 
(2016) calls 'authentic agritourism' is tourism like that promoted by the Austrian national organization Urlaub am Bauernhof (Holidays on the Farm, UaB). However, in Tyrol, only around 330 farms are a member of the association, which represents only a small share of all farms offering accommodation.

\section{Cases and methodology:}

For our investigation in the case study area of the whole Ötztal valley, Tyrol, Austria, we applied a mixed method approach (Johnson et al. 2007). First, we developed a heuristic concept for categorizing the types of farms that offer farmer-based accommodation. The term 'farmer-based' refers to entities who are active in accommodation services and farming. We collected quantitative data in an online survey and carried out a qualitative focus group (Häder 2010). For our case study, we created ideal types of farmer-based accommodation along the relation between farm activity and touristic activity. We assigned farmer-based accommodation holdings to three different ideal types defined a priori: 1 . decoupled farmer-based accommodation, 2a. Directly coupled farmer-based accommodation, and $2 b$. Indirectly coupled farmer-based accommodation.

\section{Discussion and conclusion:}

Results reveal the importance of farmer-based accommodation even if decoupled from farm activities within the case study area. In addition to providing the 'authentic' form of farmer-based tourism, this type also supports the existing agricultural structure and contributes to the positive impact of mountain farming, such as the maintenance of multifunctional cultural landscapes, the provision of ecosystem services, and the viability of rural communities. Therefore, we suggest considering decoupled forms of farmer-based accommodation as agritourism.

\subsection{Community resilience}

A second focus was laid on community resilience, shifting from the perspective of the individual farm to the surrounding socioeconomic context. The project investigated the impact of different trajectories of tourism development and integration of farming on community resilience.

\section{Impact of tourism on two villages with different trajectories: Vent and Obergurgl (Tyrol) (Stotten 2020b)}

\section{Background and question:}

See information on Vent and Obergurgl in Chapter 2.7. The article illustrates the tourist development of these villages. It focuses on tendencies of urbanization and invented traditions.

\section{Trajectories: tourist development in the 19th and 20th centuries:}

Until the $19^{\text {th }}$ century, the communities of Vent and Obergurgl lived mainly on cattle breeding and selling dairy products in the valley. But the beginning of industrialization in the Alps forced the rural population to find alternative models of existence. Both communities benefited from the efforts of individual people. In Vent, the priest Franz Senn significantly contributed to the development of mountaineering tourism by facilitating the expansion of hiking trails, an increase in accommodation services, and by training mountain guides. He intended to attract the wealthy urban population to the mountains to provide an additional income for the rural population. Due to the early development of mountaineering tourism, overnight stays in summer dominated in Vent until the 1970s (Oberwalder 2004). The population of Vent consistently rejected a development towards mass ski tourism and, instead, specialized in extensive tourism as a starting point for (high) alpine ski and mountaineering tours (Haßlacher 2004). Up until the beginning of the 20th century, Obergurgl had fewer overnight stays 
than Vent because initially endogenous agricultural intensification was perceived more profitable for the valley. It wasn't until the beginning of the 20th century that the Scheiber family recognized the importance of tourism, built hotels and campaigned for the construction of roads $(1936,1959)$ and ski areas $(1948,1950)$ (Patzelt 1989). So far only a few influential local families have driven the development of Obergurgl towards mass tourism. Overall, there are close dependencies between tourism and agriculture. Agriculture maintains the cultural landscape and sells land for the construction of tourist infrastructures. In return, tourism provides an additional income for farmers.

\section{Urbanization and invented tradition:}

With the development of tourism, the population multiplied from the mid-19 $1{ }^{\text {th }}$ century to reach 492 inhabitants in Obergurgl and 146 inhabitants in Vent. However, the number of beds exceeds the population ten- or seven-fold. The construction of tourist infrastructures has led to a process of urbanization with high settlement pressure on both villages (Andexlinger 2015). The development pathway of Obergurgl relies primarily on high-priced winter tourism that abuses natural resources and only fully utilizes the infrastructure for four months a year. Vent, on the other hand, positions itself in gentle tourism, which protects natural resources and makes equal use of infrastructures in summer and winter. Both villages preserve traditions such as farming activities, traditional costumes and local dialects. However, the tourism industry has destroyed the pre-capitalist structures of the agricultural communities, as Lefebvre (Schmid 2005) described earlier for urban areas. Therefore, the article speaks of invented traditions (Hobsbawm and Ranger 2012) that artificially construct a continuity with the past to consolidate the collective identity of the local population. Identity changes only slowly and does not match the rapid change from an agricultural to a service society.

Lock-ins and community resilience: the example of two contrasting trajectories in the Austrian Alps (Stotten et al. submitted a)

\section{Background, gap, and research questions:}

In recent decades, the approach of resilience thinking has become increasingly prominent as a defining concept for rural development (Freshwater 2015). The concept of community resilience has the advantage that it integrates dynamic processes and change. Using the case of remote rural communities in the Austrian Alps, this paper examines how different long-term development trajectories in tourism in interaction with farming play out on the resilience of rural communities. More specifically, we empirically apply the community resilience concept in two case villages within one municipality at two different points in time to consider longitudinal aspects of community resilience over time. In our analysis, we review data of a well-documented Man-and-the-Biosphere (MAB) project from the 1970s through the conceptual lens of community resilience. To evaluate the impact of the different trajectories on community resilience, we conducted a broad data collection in the same two villages that had been chosen in the MAB study. This longitudinal approach provides a dynamic perspective to better understand the importance of path dependencies for resilience processes.

\section{Theoretical concepts:}

Two forms of resilience can be distinguished: reactive emergency resilience, which addresses sudden negative disruptions, and proactive resilience in everyday life (DeVerteuil and Golubchikov 2016). To demonstrate resilience at community-level, it is crucial to understand the complex interplay of economic, social, cultural, political and natural domains that shape a socio-ecological system (Kelly et al. 2015; Emery und Flora 2006). Building on this, communities are strongly resilient when all five domains 
are well developed, though single domains are usually more weakly developed than others (Adger 2000). Development pathways consist of the total of cumulative actions of individuals and stakeholder groups. Path dependencies refer to communities generating positive or negative trajectories that are often shaped by lock-in effects (Wilson 2012b).

\section{Cases and methodology: see Chapters 2.7 and 3.1.}

\section{Discussion and conclusion:}

This empirical study demonstrates two diverging trajectories that result in different sets of economic, social, cultural, political and natural domains and how communities are locked into specific resilience response pathways. The evolution of resilience domains differs greatly in Obergurgl and Vent. However, both villages lack resilience mostly in social terms, caused by different lock-ins. In Obergurgl diverging interests between stakeholder groups and a one-sided focus on winter tourism weakens social cohesion and the seasonal outmigration produces economic lock-ins. In Vent, the low number of residents generates structural lock-ins. The conclusions drawn from our investigation of the two case study areas as examples of remote mountain communities highlights different trajectories even with similar economic (dependency on tourism), structural (declining social cohesion) and political (dominance of strong political groups related to one wider family) lock-ins resulting in path dependencies. The recent crisis of Covid 19 might be used by the communities as an opportunity to launch a social-ecological transition from the current regime into another, more resilient, one (Folke, Carl, Carpenter, Stephen R. et al. 2010).

\subsection{Ecological resilience}

Finally, farm resilience and community resilience are closely intertwined with ecological resilience, understood here as the provision of ES which form a basis for local livelihood and economic activities.

\section{Impact of socioeconomy on the landscape development in the villages of the municipality Sölden (Master Thesis) (Sulzer 2018)}

\section{Cases and methodology:}

As case study site, the whole municipality Sölden was chosen; for methodology, see Chapter 3.4.

\section{Historical landscape change:}

Vent and Obergurgl had both been typical agricultural villages with a large share of grassland of low land-use intensity (non-fertilized pastures and meadows), a smaller share of grassland of high land-use intensity (fertilized meadows), but no croplands. After 1860, however, both case study sites reveal a sharp decrease in grassland of high and low land-use intensity and an increase in unused grasslands, dwarf shrubs and forests, which reflects the agricultural abandonment of grassland. Moreover, the local glacier area decreased significantly from 1860 to today, while all sparse vegetation types at higher elevations increased. 

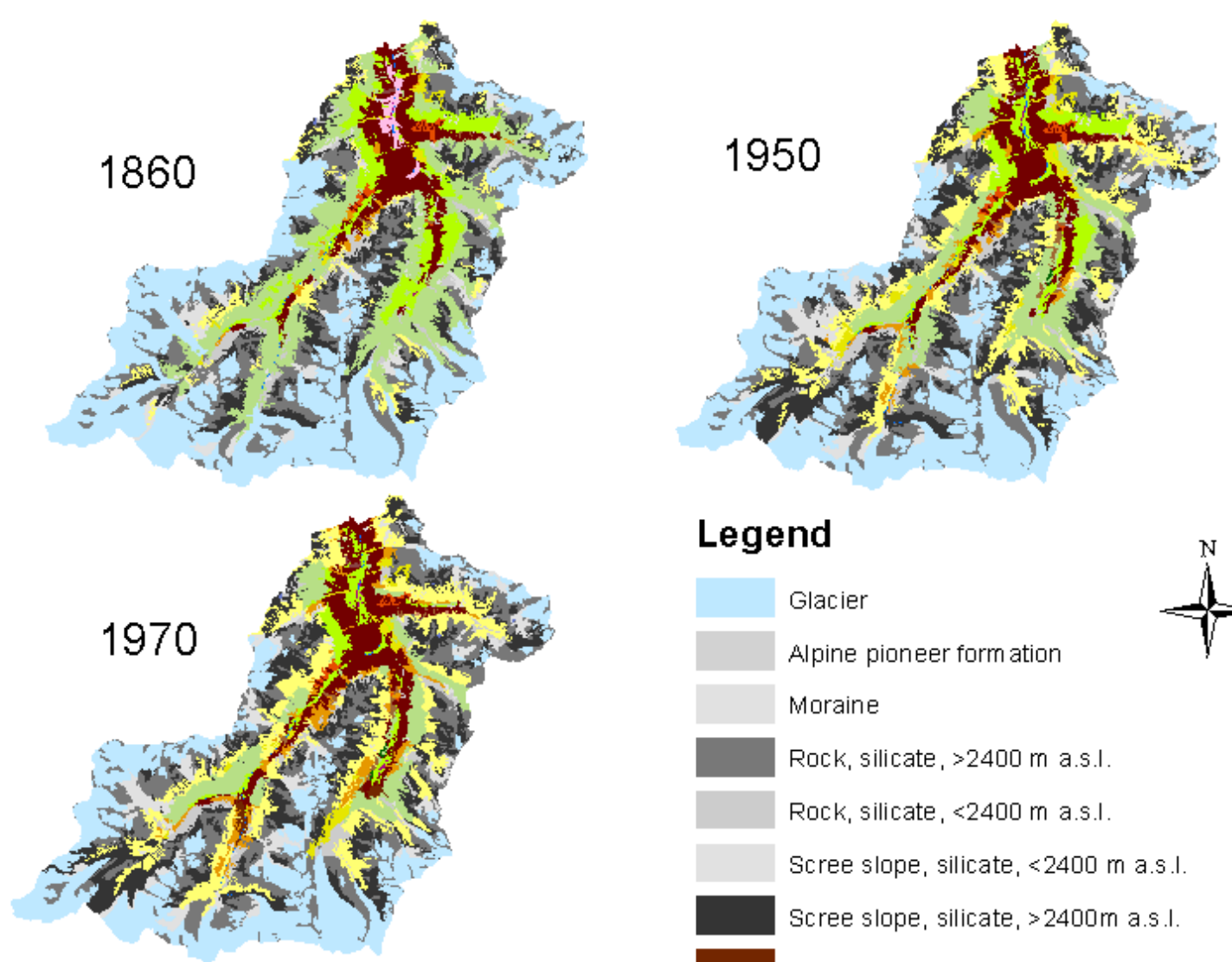

\section{Legend}
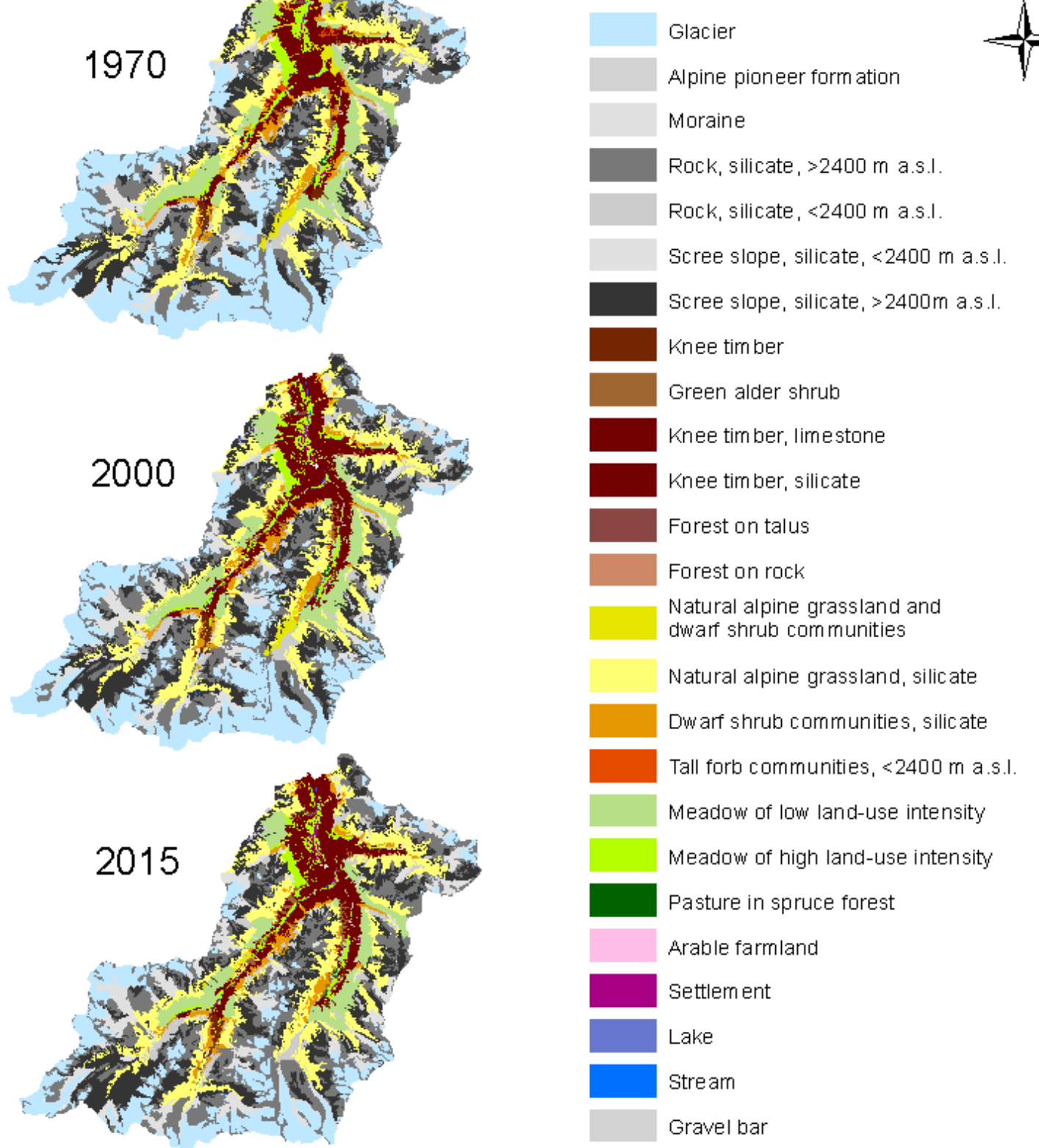

Figure 3: Land use and land cover maps for the municipality of Sölden (adapted from Sulzer 2018) 


\section{Connection to socioeconomic developments}

The appearance and quality of the landscape is closely connected to political, economic and demographic developments in the region. In Obergurgl and Vent, the economic focus changed from agriculture to tourism and triggered the abandonment of pastures and meadows, especially on steep slopes and at higher altitudes. But while Vent focused on gentle tourism and only slightly expanded the settlement area, Obergurgl significantly altered the scenery with hotel complexes and skiing facilities. However, while larger areas of grassland were abandoned at high altitudes in Vent, more grassland was maintained at lower management intensities in Obergurgl to keep the landscape open for ski slopes.

Perception of the supply of ecosystem services in the Upper Ötz Valley (Master Thesis) (Gruber 2019)

Cases and methodology:

Case study site was Obergurgl and Vent; for methodology, see Chapter 3.3.

\section{Perceived supply of ES:}

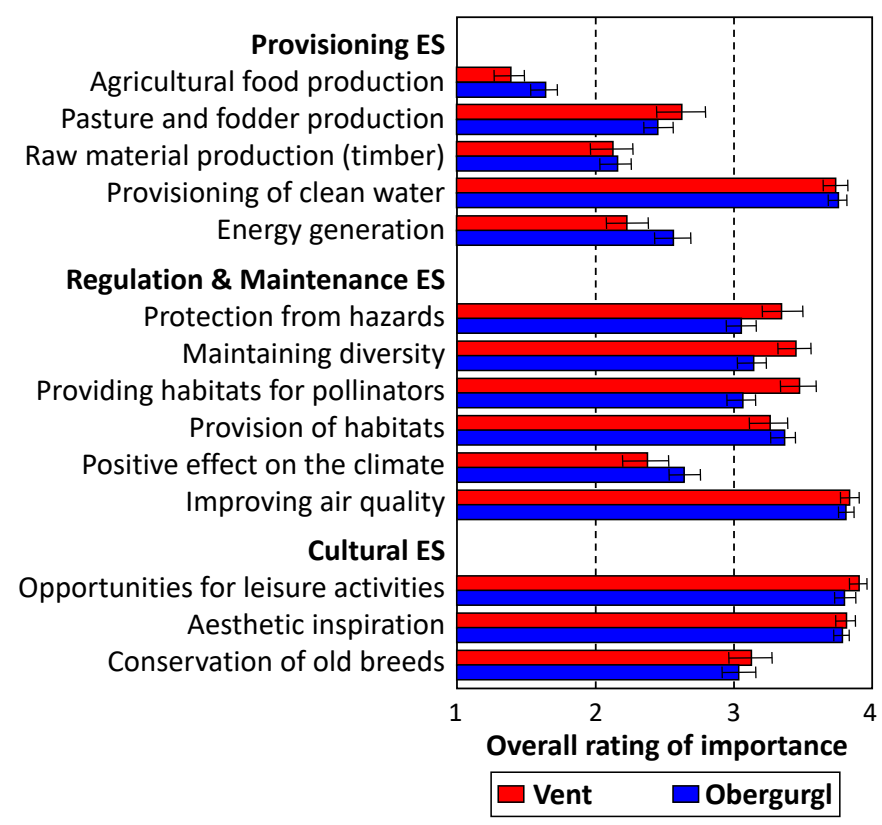

Figure 4: Mean perceived ecosystem service supply based on the existing natural capital of the most relevant ES in the study areas (adapted from Stotten et al., submitted b). Values range from 1 (not important) to 4 (very important). Ecosystem service classification according to CICES (Haines-Young and Potschin 2018).

The perceived supply of natural capital to ES is almost the same in the study areas of Obergurgl and Vent. Significant differences in the assessment between the two villages could be demonstrated for the ES 'Protection from hazards' $(p=0.045)$, 'Providing habitats for pollinators' $(p=0.009)$, and 'Maintaining biodiversity' $(p=0.023)$. The perceived supply in Vent is higher for all three ES. Overall, the contribution to typical ES that is based on agricultural and forestry management, i.e. food and fodder production, raw material, and energy production, is rated as low (mean values between about 2.5 and 3.5). The perceived contribution of the natural capital to the cultural services of 'Opportunities for leisure activities' and 'Aesthetic inspiration' as well as to Regulation \& Maintenance ES, such as 'Provision of clean water' and 'Improving air quality', is rated as highest (mean values around 1.2). Closely 
followed by Regulation \& Maintenance such as 'Protection from hazards', 'Maintaining diversity', and 'Provision of habitats' (between 1.5 and 1.9).

Does socioeconomic diversification enhance multifunctionality of mountain landscapes? (Huber et al. 2020)

Background, gap and research question:

Multifunctional landscapes counter conflicts and optimize benefits for competing stakeholders. Moreover, they make an efficient use of space and time, which is particularly useful in mountain valleys with limited usable land. Multifunctionality is essential for developing sustainable and resilient landscapes in order to withstand the challenges of global change and to meet the needs of future generations. Despite multifunctionality being a frequently mentioned policy aim, there has been a lack of implementation, mainly due to knowledge gaps about direct and indirect implications of land-use decisions on multifunctionality. Although numerous studies have assessed human-induced trajectories of landscape patterns and related effects on selected ES (Bürgi et al. 2015; Egarter Vigl et al. 2017; Schirpke et al. 2019; Zimmermann et al. 2010), few studies have assessed the historical change in multifunctionality and how it is influenced by the conversion of land use types and the adaptation of landscape patterns (Lavorel et al. 2019; Tasser et al. 2020). This paper aimed to improve our understanding of interlinkages between socioeconomic developments, landscape patterns and multiple ES supply (i.e., multifunctionality).

\section{Cases and methodology:}

The whole municipality of Sölden was chosen as case study site; for the methodology of ES modelling, see Chapter 3.5. All six ES were considered equally important and their changes from 1860 on were rescaled to values between 0 and 1 and summed to a multifunctionality indicator.

\section{Historical change of landscape and multifunctionality:}

We revealed significant changes in landscape pattern, a significant decline in provisioning ES and an increase in cultural and regulating ES between 1860 and 2015. Overall, multifunctionality (i.e., the sum of ES; Figure 3) decreased from 1860 to the middle of the twentieth century and increased afterwards. These changes in multifunctionality can be explained by climate- and human-induced changes in landscape composition, particularly by an increase in the diversity of land use/land cover (LULC) types and a decrease in glacier and unused grassland areas. The composition of the landscape was altered by the inhabitants as the economic focus shifted from agriculture to tourism. 


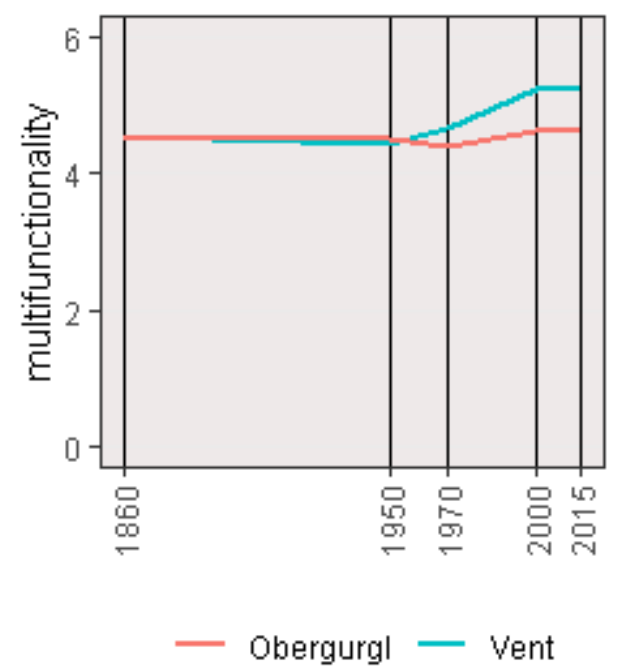

Figure 5: Changes in multifunctionality (adapted from Huber 2020). To get the multifunctionality indicator, all six ES were considered equally important and their changes from 1860 on were rescaled to values between 0 and 1 and summed.

The interplay of agriculture and tourism:

Except for glacier retreat, all factors influencing the multifunctionality are driven by the interplay of agricultural and tourism activities. When the economy is too oriented towards food or timber production, regulating and cultural services may suffer. In contrast, low-intensity agricultural activities support the supply of manifold ES, not only of intended agricultural ES, but also of unintended ES, such as 'recreation' or 'aesthetic value'. Hence the reduction of agricultural use enhances multifunctionality, whereas agricultural abandonment leads to multifunctionality loss (Stürck and Verburg 2017). In this context, the tourism sector is the counterpart to the agricultural sector. On the one hand, the tourism domain has the potential to broaden the range of supplied ES by extensifying agricultural production and increased accessibility. On the other, high tourism intensity can also reduce ES supply indirectly by replacing agricultural activities and co-produced ES or directly by negatively influencing biodiversity (Hall 2010; Wipf et al. 2005) and cultural ecosystem services (Taff et al. 2019).

Conclusion:

Our findings lead us to conclude that a status of stable and balanced supply of the six ES is supported by local livelihoods that are balanced between agriculture and tourism. We recommend supporting low-intensity agricultural activities and controlling human interference in the landscape with designated protection areas in order to sustain multiple ES and preserve landscape multifunctionality for livelihoods and the well-being of the rural communities.

Change from agricultural to touristic use: Effects on the aesthetic value of landscapes over the last 150 years (Schirpke et al. 2019)

\section{Background, gap and research question:}

The demand for cultural ecosystem services (CES) is increasing and aesthetic values contribute substantially to attract visitors to mountain regions, enhancing socioeconomic well-being. While most studies focused on the assessment of aesthetic values under current conditions, this study aimed to evaluate the historic development of aesthetic values from the perspective of today by analysing 
changes in the actual supply of CES along roads and paths in the municipality Sölden since the beginning of tourism.

\section{Cases and methodology:}

We mapped roads and paths for the municipality of Sölden and for five time steps over the last 150 years to then estimate aesthetic values along these infrastructures, using a spatially explicit modelling approach (Schirpke et al. 2013b; Schirpke et al. 2016).

\section{Changes in aesthetic value:}

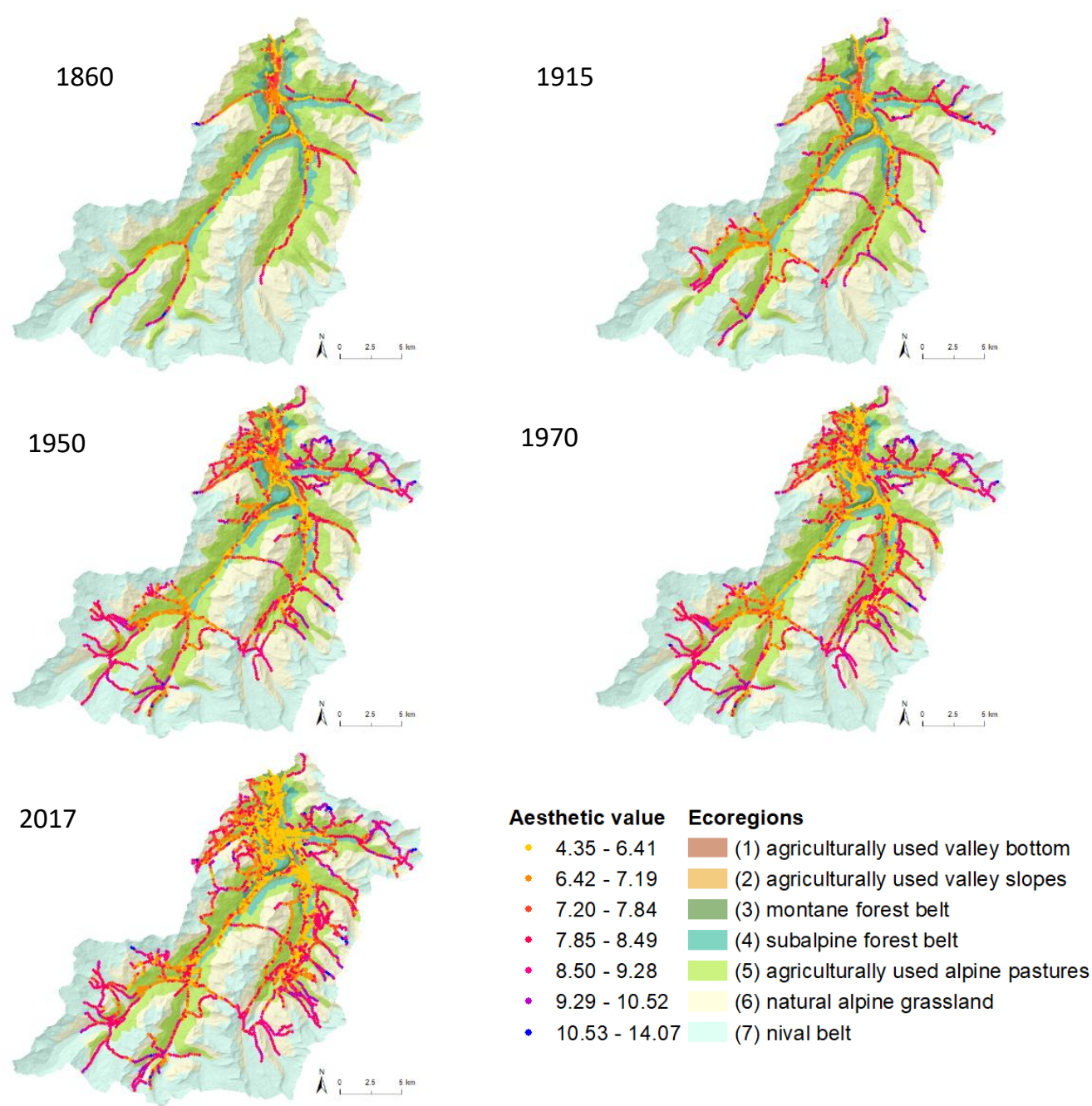

Figure 6: Changes in aesthetic values along the road network from 1860 to 2017.

Our results (Figure 6) indicate that increased access to areas of high aesthetic values was related to general increases in the supply of aesthetic values until 1950. Although the accessibility to high-elevation areas continued to increase until 2017, aesthetic values generally decreased due to landscape changes induced by the shift from mainly agricultural to touristic use. On the valley floor, the decrease in aesthetic values can be explained by a greater amount of settlements and infrastructure in recent times. Furthermore, the densification of the formerly open forests also has a negative impact on aesthetic values. At higher elevations, the abandonment of pastures and the subsequent reforestation processes negatively affect aesthetic values. 


\section{Conclusion:}

If carefully planned and managed, mountain regions may actively enhance aesthetic experiences and foster touristic use by providing good infrastructure, but land use policies and landscape management should support agricultural activities to maintain high levels of aesthetic values.

\subsection{Social-ecological resilience}

As a cooperation between sociologists and ecologists, the project combines socioeconomic research with ecologic research to investigate the resilience of the social-ecological system.

Social-ecological resilience in remote mountain communities: towards a novel framework for an interdisciplinary investigation (Stotten et al. submitted b)

Background, gap and research question:

Remote mountain communities in the European Alps are facing numerous social, economic and ecological challenges (Zucca 2006). Moreover, the interplay of natural factors and social drivers makes remote mountain communities complex social-ecological systems (SES) that have multiple characteristics and are challenging to understand (Dorward 2014). This makes it difficult to create frameworks that integrate social and ecological science aspirations to examine and evaluate the sustainability and resilience of such SES. Drawing on a field study conducted in two remote villages of the Ötztal Valley in the Austrian Alps, we aim at providing insights into the interplay of tourism and farming within an SES, the provision of ecosystem services (ES), and how it affects the social-ecological resilience of remote mountain communities.

\section{Case study site and methodology:}

The case study sites are Vent and Obergurgl. First, we introduce a novel framework, relying on the Sustainable Livelihood Framework (Scoones 1998) and integrating the Community Resilience (Wilson 2010, 2012a, 2012b) and Ecosystem Services (Groot et al. 2002; Millennium Ecosystem Assessment 2005) concepts. Based on this framework, we reveal aspects that contribute to the resilience of the communities in the case study sites (Vent and Obergurgl), especially examining tourism and farming activities. We further highlight the local provision of ES.

\section{Conceptual framework:}

The newly developed framework (see Figure 7) integrates the SRL framework with the concepts of community resilience and ES to better understand the interlinkages of farming and tourism as well as its impact on the SES. Within the framework, the social, economic, political, cultural and natural capitals stand for assets. The external and internal drivers represent everything influencing these capitals. External drivers forwarded by agents form the wider conditions on a global and regional scale and shape the external context for vulnerabilities and opportunities. Through the interaction with the other capitals, the natural capital is able to provide ES (potential ES supply) (Costanza et al. 2014). Influenced by the status of the capitals and by internal and external drivers, residents decide on various livelihood strategies, i.e. they decide how to use their capitals to generate specific ES flow and income. These livelihood strategies are expressed as desires for certain ES (ES demand) that lead to specific actions or activities to enhance the supply or to 'harvest' the desired ES. The resulting livelihood outcome includes the ES flow or the income. ES flows and incomes in turn influence the capital; this can trigger changes in the livelihood strategy and the livelihood outcomes in a subsequent period. 


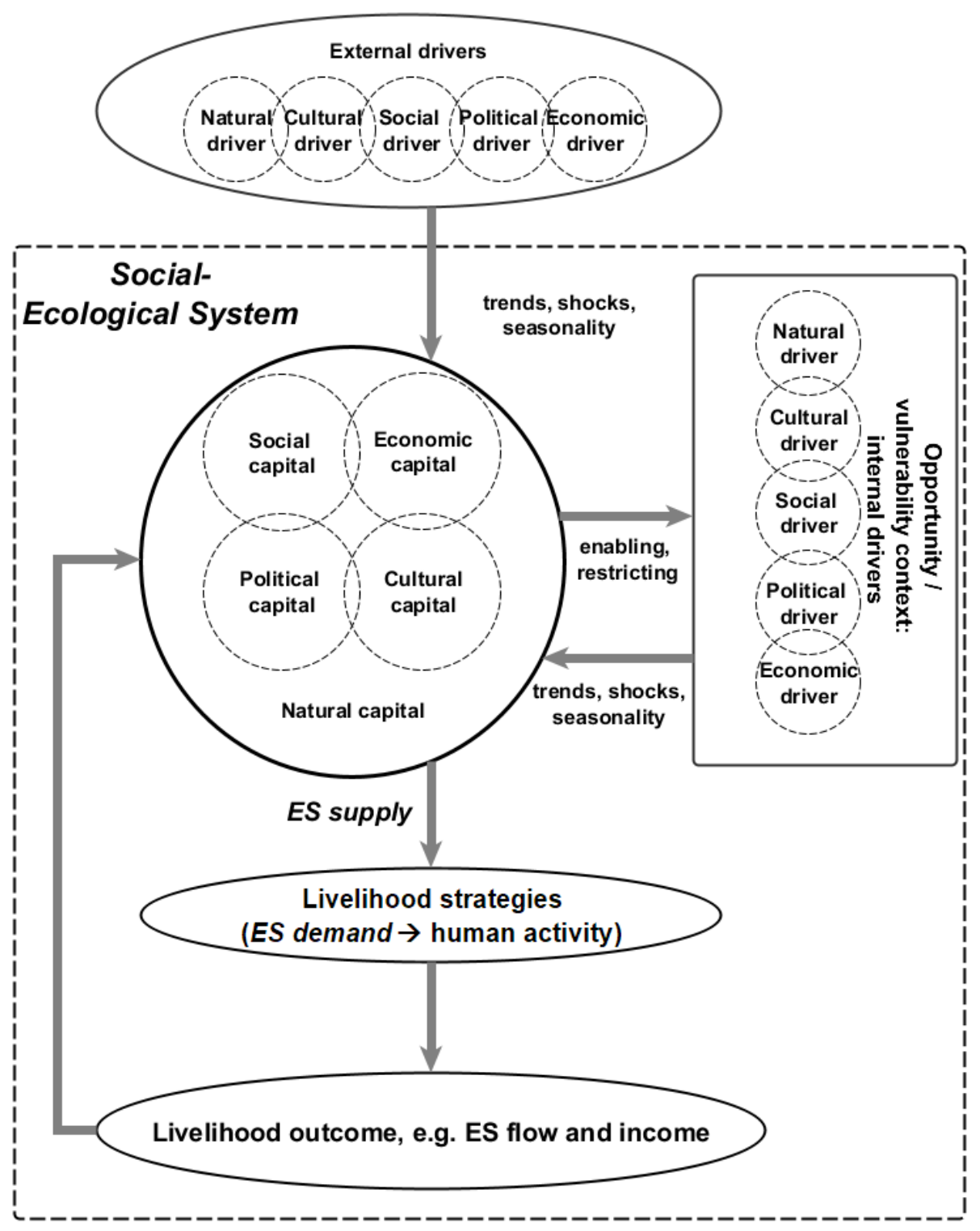

Figure 7: Framework to evaluate the resilience of social-ecological systems by combining sustainable rural livelihoods and ecosystem service concepts (adapted from Stotten et al. submitted b).

To come up with a summarizing assessment on the capital status and the livelihood outcome, we used a modified Shannon-Wiener index (Spellerberg and Fedor 2003). The Shannon-Wiener index ( $\left.H^{\prime}\right)$ measures the diversity of items and their proportional abundances $\left(p_{i}\right)$ :

$H^{\prime}=-\sum_{i=1}^{R} p_{i} \ln p_{i}$

In our case, this is calculated by multiplying the capitals with the effects of the strategies and standardizing them in comparison to a 'best case situation' (i.e., a highly positive capital multiplied with a highly positive strategy; $0.9 \times 0.9$ ) (see Table 3 ). By this modification of the calculation method for $\mathrm{p}_{\mathrm{i}}$, we ensure that the index takes the value 1 when all capitals are equally balanced at a high status and increased by the livelihood strategies. The Shannon entropy $(\min =0)$ is smaller when the capitals are more unequal, and when the livelihood strategies lower the capitals. 


\section{Discussion and conclusion:}

In the case studies, Vent showed a higher social-ecological resilience on the four investigated strategies than Obergurgl. However, these results are subjective because of the methodological procedures and do not cover the full background information (e.g., reasons for the moderate social capital that differs for the two mountain communities). The novel framework is based on the elaborated framework that integrates the concepts of community resilience and ES and provides a richly textured framework for understanding the subtleties of the resilience of a SES. The novel framework has the potential to reveal the social valorization and the social demand of a single ES. Here we agree with Adger (2000) that social resilience, including economic, social, cultural and political capital, depend on the ecological system and, thus, the natural capital. Even if the original SRL framework was developed to understand the complexities of poverty in the Global South, the novel framework has enhanced the SRL framework and made it suitable for application in remote mountain areas. With emphasis on the natural capital and the integration of the ES concept, we revealed complex interdependencies of social and ecological resilience. By applying the novel framework to case study sites in the Austrian Alps with combined sociological and ecological research approaches, we demonstrated how a detailed image can be drawn of the complex interplays of several drivers and capitals shaping the SES. Nevertheless, our case study area demonstrates that the complexities of an SES make it impossible to grasp all aspects in a schematization; thus, the novel framework strives to be holistic without claiming to be so.

Table 3: Illustrative summary of the effects of the livelihood strategies on the mean class status of the capitals as the basis for the evaluation of resilience for Obergurgl and Vent (adapted from Stotten et al. submitted b). Key: ++ (0.9) highly positive, + (0.7) positive, o (0.5) neutral, - $(0.3)$ negative and - (0.1) highly negative impact of the strategy on the respective capital.

\begin{tabular}{|c|c|c|c|c|c|c|c|c|c|c|}
\hline \multirow[b]{2}{*}{ Capitals } & \multicolumn{2}{|c|}{ Capital status } & \multicolumn{2}{|c|}{ Agricultural strategy } & \multicolumn{2}{|c|}{ Touristic strategy } & \multicolumn{2}{|c|}{$\begin{array}{c}\text { Land management } \\
\text { strategy }\end{array}$} & \multicolumn{2}{|c|}{ Water use strategy } \\
\hline & Obergurgl & Vent & Obergurgl & Vent & Obergurgl & Vent & Obergurgl & Vent & Obergurgl & Vent \\
\hline Economic & $++(0.9)$ & $0(0.5)$ & $0(0.5)$ & $0(0.5)$ & $++(0.9)$ & $+(0.7)$ & $+(0.7)$ & $0(0.5)$ & $+(0.7)$ & $+(0.7)$ \\
\hline Social & $0(0.5)$ & $0(0.5)$ & $-(0.3)$ & $+(0.7)$ & $-(0.3)$ & $+(0.7)$ & $0 /-(0.4)$ & $+(0.7)$ & $0(0.5)$ & $0(0.5)$ \\
\hline Cultural & $+(0.7)$ & $+(0.7)$ & $--(0.1)$ & $++(0.9)$ & $+(0.7)$ & $+(0.7)$ & $-(0.3)$ & $+(0.7)$ & $+(0.7)$ & $0(0.5)$ \\
\hline Political & $+(0.7)$ & $0(0.5)$ & $0(0.5)$ & $0(0.5)$ & $++(0.9)$ & $0(0.5)$ & $0 /-(0.4)$ & $0 /-(0.4)$ & $0(0.5)$ & $0(0.5)$ \\
\hline Natural & $+(0.7)$ & $++(0.9)$ & $-(0.3)$ & $+(0.7)$ & $-(0.3)$ & $+(0.7)$ & $-(0.3)$ & $+(0.7)$ & $-(0.3)$ & $0(0.5)$ \\
\hline \multicolumn{3}{|c|}{ Total effect $\left(H^{\prime}\right)$} & $0(0.44)$ & $+(0.64)$ & $+(0.62)$ & $+(0.64)$ & $0(0.50)$ & $+(0.61)$ & $0(0.58)$ & $0(0.57)$ \\
\hline \multicolumn{3}{|c|}{$\begin{array}{r}\text { Social-ecological resilience of strategies } \\
\text { under investigation }\end{array}$} & \multicolumn{8}{|c|}{ Obergurgl: 0 (0.54), Vent: $+(0.61)$} \\
\hline
\end{tabular}




\subsection{Resilience approaches}

For a cooperation with the touRES project (see Chapter 5.4), we integrated a fourth research question in our work: How to define, operationalize and assess the resilience of mountain regions, communities and environments?

Two Perspectives - One Goal: Resilience Research in Protected Mountain Regions (Huber et al. submitted)

Background, gap and research question:

Resilience at various levels of the social and environmental sphere is a key aspect of sustainable development in mountain areas. But despite ongoing research efforts (e.g. Nettier et al. 2017; Ingrisch and Bahn 2018), the question of how the resilience of mountain regions, communities and environments can be defined, operationalized and assessed, remains difficult to answer. Different resilience concepts are used interchangeably and/or with ambiguous meanings (Gardner and Dekens 2007; Hosseini et al. 2016). In our cooperation, we compared two different empirical approaches to analyse the resilience of protected mountain areas based on two case studies from the Austrian Alps and the Nepalese Himalayas and discussed a more holistic understanding of mountain resilience.

\section{Theoretical concepts:}

In traditional research of social-ecological resilience, the research focus is set on systems - whether ecological, social or social-ecological - resulting in a resilience discourse dominated by system-oriented analytical approaches (Bohle et al. 2009). However, researchers argue that transferring ideas about (ecological) systems uncritically to the social sphere is questionable (Cote and Nightingale 2012; Davoudi et al. 2012). In contrast to system-oriented perspectives on resilience, some recent approaches follow actor-centred perspectives. These approaches move social entities and their agency to the centre of attention (Bohle et al. 2009; Bristow und Healy 2014).

\section{Comparison of the two projects:}

Both projects (RESULT and touRES) investigated the resilience of livelihoods in mountain regions under changing socioeconomic (e.g. change of economic structure) and environmental (e.g. climate change, natural hazards) conditions. However, different approaches are used to investigate the resilience of livelihoods involving different scales of analysis and methodologies, which are outlined in an analytical grid (Table 4). We framed five dimensions that characterize the approaches of mountain resilience research: resilience of who/what; scope/scale of analysis; resilience to what; methodological approach; and aim of analysis.

\section{Discussion and conclusion:}

As both approaches (see above) have strengths and weaknesses in applicability, an integration of the two should be aimed at. To model complex system phenomena that involve human or institutional behaviour, it can be helpful to use an agent-based modelling approach. Here, we recommend inviting practitioners to define the behaviour of the model agents, which is called 'participatory agent-based modelling'. Stakeholder involvement in the modelling processes can reduce the inherent limitations and improve understanding of the relevant system components (Voinov and Bousquet 2010); in this 
way, participatory modelling not only helps the scientists to incorporate local knowledge to system modelling but also enhances the stakeholders' system knowledge and gives them a chance to reflect possible consequences of their individual willingness to act.

Table 4: Analytical grid of characteristics in the two projects' views on resilience (Huber et al. submitted).

\begin{tabular}{|c|c|c|}
\hline Dimension & RESULT & touRES \\
\hline 1 Resilience of who/what & $\begin{array}{l}\text { Mountain social-ecological systems } \\
\text { (mountain ecosystems and their local in- } \\
\text { habitants) }\end{array}$ & Individuals (touristic entrepreneurs) \\
\hline 2 Scope/Scale of analysis & System-based & Agency-based \\
\hline 3 Resilience to what & $\begin{array}{l}\text { Long-term changes in climate and socio- } \\
\text { economic trajectories }\end{array}$ & Natural hazards \\
\hline 4 Methodological approach & $\begin{array}{l}\text { Mapping, modelling and quantifying eco- } \\
\text { system services (by spatial modelling in } \\
\text { geographic information systems, surveys, } \\
\text { expert interviews) }\end{array}$ & $\begin{array}{l}\text { Understanding poly-rational values and } \\
\text { worldviews, evaluating actions taken/not } \\
\text { taken (by surveys and interviews), natural } \\
\text { hazards analysis }\end{array}$ \\
\hline 5 Aim of analysis & $\begin{array}{l}\text { Develop recommendations to ensure and } \\
\text { improve the supply of ecosystem services } \\
\text { to local inhabitants }\end{array}$ & $\begin{array}{l}\text { Improve local optimum by identifying the } \\
\text { range of actions people are able and will- } \\
\text { ing to take that increase their resilience } \\
\text { to natural hazards }\end{array}$ \\
\hline
\end{tabular}

\section{$5 \quad$ Outputs}

\subsection{Deliverables}

Throughout the research project, we produced a range of valuable results for science as well as for practice. To spread these results in both fields, we published in high-ranking academic journals and spoke at international conferences, and we organized public events with local experts and interested people in the field of regional development (see Figure 8). With this double strategy, we aimed at introducing the local knowledge gathered in Vent and Obergurgl into the international research community, and at giving back scientific knowledge to the local stakeholders to support resilient local development.

For the academic field, we published respectively submitted a total of eight papers in high-ranking scientific journals in the disciplines of ecology (e.g. Journal of Ecosystem Services), social science (e.g. Journal of Social Economics), and transdisciplinary studies (e.g. Journal of Sustainability). Additionally, we gave 13 oral presentations and five poster presentations at national and international conferences (e.g. EGU - European Geosciences Union General Assembly, Vienna, 8-13 April 2018; 13th European IFSA Symposium. Chania, Greece, 4 July 2018). Our results attracted great interest within the scientific community and are now part of the general knowledge about socio-ecological resilience in agriculture and tourism. For the dissemination of results in the field of practice, we organized one teacher training at the Federal Ministry of Education, Science and Research in 2019, and four local public events. One of these events was the local stakeholder workshop at the University Centre in Obergurgl, where local community members were invited to discuss the findings (see below). We also participated in the Lange Nacht der Forschung event at the University of Innsbruck in 2018, and at the University of Bolzano in 2019, and we organized a session at the Tag der Alpinen Forschung 2019 organized by the Alpine Research Centre Obergurgl at University Center Obergurgl. With these events, we sensitized 
local decision makers and the local public to the variables of, and strategies for resilient regional development. Finally, we continue to introduce the results of the research project into the teaching at the departments of Sociology and Ecology. In this way, our findings contribute to the training of nextgeneration decision makers in agriculture, tourism and regional development.

All disseminations are presented below in detail:

\section{Scientific papers:}

- Huber, Lisa; Posch, Eva Luise; Höferl, Karl Michael; Bell, Rainer; Stotten, Rike; Tasser, Erich et al. (submitted): Two Perspectives - one Goal: Resilience Research in Protected Mountain Regions. In: Ecomont.

- Huber, Lisa; Schirpke, Uta; Marsoner, Thomas; Tasser, Erich; Leitinger, Georg (2020): Does socioeconomic diversification enhance multifunctionality of mountain landscapes? In: Ecosystem Services 44. DOI: 10.1016/j.ecoser.2020.101122.

- Stotten, Rike (2020a): The role of farm diversification and peasant habitus for farm resilience in mountain areas: the case of the Ötztal valley, Austria. In: International Journal of Social Economics. DOI: 10.1108/IJSE-12-2019-0756.

- Schirpke, Uta; Altzinger, Andreas; Leitinger, Georg; Tasser, Erich (2019): Change from agricultural to touristic use: Effects on the aesthetic value of landscapes over the last 150 years. In: Landscape and Urban Planning 187, S. 23-35. DOI: 10.1016/j.landurbplan.2019.03.004.

- Stotten, Rike (2020b): Tourismuseinwirkungen auf zwei Dörfer mit unterschiedlichen Entwicklungs-pfaden: Vent und Obergurgl (Tirol). In: Jahrbuch für Geschichte des ländlichen Raumes. (forthcoming)

- Stotten, Rike; Schermer, Markus; Wilson, Geoff (submitted a): Lock-ins and community resilience: the example of two contrasting trajectories in the Austrian Alps. In: Journal of Rural Studies

- Stotten, Rike; Huber, Lisa; Tasser, Erich; Leitinger, Georg (submitted b): Social-ecological resilience in remote mountain communities: towards a novel framework for an interdisciplinary investigation. In: Ecology and Society.

- Stotten, Rike; Maurer, Michaela; Herrmann, Hannes; Schermer, Markus (2019): Different Forms of Accommodation in Agritourism: The Role of Decoupled Farmer-Based Accommodation in the Ötztal Valley (Austria). In: Sustainability 11 (10), S. 2841. DOI: 10.3390/su11102841.

\section{Oral presentations:}

- Huber, Lisa; Bahro, Nico; Leitinger, Georg; Tappeiner, Ulrike; Strasser, Ulrich (2018): Aqua.MORE: Sociohydrological Modelling of Water Resources in an Alpine Catchment. At: EGU - European Geosciences Union General Assembly, Vienna, 8-13 April.

- Tasser, Erich (2018): Selbstversorgungsgrad und Landnutzung in Tirol. At: Workshopreihe: Der Zukunft den Boden bereiten. Innsbruck, 16 May. (on invitation)

- Huber, Lisa (2018): Socio-hydrological modelling of water resources in Alpine Areas. At: Productive Mountains, Venice / Val Comelico, 21-23 June.

- Stotten, Rike; Leitinger, Georg (2018): New Farming Arrangements for Resilience. At: $13^{\text {th }}$ European IFSA Symposium. Farming systems: facing uncertainties and enhancing opportunities. Chania, Greece, 4 July.

- Altzinger, Andreas; Schirpke, Ute; Leitinger, Georg; Tasser, Erich (2018): Land-use changes in alpine regions: effects on the aesthetic value. At: GfÖ Annual Meeting 2018, Vienna, 10-14. September.

- Stotten, Rike; Herrmann, Hannes (2018): Community resilience in mountain areas: evidence of a qualitative approach in the Austrian Alps. At: Forum Origin, Diversity, Territories. Turin, Italy, 19 September.

- Stotten, Rike; Herrmann, Hannes; Maurer, Michaela (2018): The impact of agritourism on farm resilience. Evidence from the Ötztal Valley (Tyrol). $1^{\text {st }}$ World Congress on Agritourism, Bolzano, Italy, 7 November.

- Stotten, Rike (2019): Self-governance as a strategy for farm resilience. New Directions in Agri-Environmental Governance. Practices of inclusion, collaboration, reflexivity and reconfiguration. At: Public Workshop. Neuchâtel, Schweiz, 28.- May. (on invitation)

- Huber,Lisa; Bahro,Nico; Leitinger, Georg; Tappeiner, Ulrike; Strasser, Ulrich (2019): Agent-based modelling of a coupled water demand and supply system at the catchment scale. At: International Mountain Conference, Innsbruck, 11. September.

- Stotten, Rike (2019): Farm Resilience and Ecosystem Services: Experience from the Ötztal Valley. At: International Mountain Conference, Innsbruck, 9. September. 
- Stotten, Rike; Herrmann, Hannes (2019): Socio-economic vulnerabilities of farming in the Upper Ötztal. At: International Mountain Conference, Innsbruck, 11. September

\section{Poster presentations (see appendix):}

- $\quad$ Leitinger, Georg; Huber, Lisa; Tasser, Erich; Altzinger, Andreas; Herrmann, Hannes; Stotten, Rike (2018): Resilience through synergies between agriculture and tourism for two contrasting trajectories in the Tyrolean Alps. Ecological Society of Germany, Austria and Switzerland. Annual Meeting. Vienna, $10-14$ September.

- Stotten, Rike; Herrmann, Hannes (2018): Community resilience in mountain areas: evidence of a qualitative approach in the Austrian Alps. Forum Origin, Diversity and Territories, Turin, Italy, 19-21 September.

- $\quad$ Leitinger, Georg; Huber, Lisa; Tasser, Erich; Herrmann, Hannes; Stotten, Rike (2019) Resilience through synergies between agriculture and tourism for two contrasting trajectories in the Tyrolean Alps. $10^{\text {th }}$ IALE World Congress, Milano, Italy 1 July.

- Huber, Lisa; Bahro, Nico; Leitinger, Georg; Tappeiner, Ulrike; Strasser, Ulrich (2019) Agent-based modelling of a coupled water demand and supply system at the catchment scale. International Mountain Conference, Innsbruck, 11 September.

- Leitinger, Georg; Schirpke, Uta; Altzinger, Andresas; Tasser, Erich (2019) The role of accessibility on the supply of aesthetic values. International Mountain Conference, Innsbruck, 11 September.

\section{Public events and other publications:}

- Huber, Lisa; Herrmann, Hannes; Leitinger, Georg; Altzinger, Andreas; Stotten, Rike (2018): Landwirtschaft in den Alpen - in einem Spannungsfeld zwischen Tourismus und Klimawandel? Lange Nacht der Forschung, Innsbruck, 13 April.

- $\quad$ Stotten, Rike; Leitinger, Georg; Huber, Lisa; Maurer, Michaela; Herrmann, Hannes (2018): Landwirtschaft im Spannungsfeld zwischen Tourismus und Klimawandel. Tag der Alpinen Forschung, Obergurgl, 28 September.

- Huber, Lisa; Stotten, Rike; Herrmann, Hannes; Leitinger, Georg (2019): Landwirtschaft und Tourismus in Obergurgl und Vent. Bundesministerium für Bildung, Wissenschaft und Forschung (BMBWF), 23 July.

- Stotten, Rike; Leitinger, Georg; Huber, Lisa; Herrmann, Hannes (2019): Landwirtschaft im Spannungsfeld zwischen Tourismus und Klimawandel. Tag der Alpinen Forschung, Obergurgl, 27 September.

- $\quad$ Stotten, Rike; Leitinger, Georg; Huber, Lisa; Tasser, Erich; Holtkamp, Carolin (2020): Ergebnispräsentation des RESULT-Projekts. Obergurgl, 30 September.

- $\quad$ Stotten, Rike; Holtkamp, Carolin; Leitinger, Georg; Huber, Lisa; Tasser, Erich (2020): Was macht unser Dorf stark? Nederblick - Gemeindeinformation Sölden Obergurgl Vent. 73. Ausgabe Dezember, S. 28.

\subsection{Stakeholder workshop}

The stakeholder workshop took place at the University Centre in Obergurgl on 30 September2020. It aimed at introducing our research findings into the local context and initiating a discussion among community members of Vent und Obergurgl about how to strengthen the social-ecological resilience at farm and community level in their villages. It was chaired by Ruth Buchauer, a professional moderator for participative events. The workshop started with a 30 min presentation of the main factors enhancing and lowering resilience in Vent and Obergurgl. The presentation was followed by a short question and answer session and a 1.5 hour World Café session. In the course of the World Café, participants first discussed the challenges to resilience in their villages and then the potentials and how they could personally contribute to enhancing resilience. In the end, participants collected all options to strengthen resilience, differentiating which ones are long term and which ones could be implemented in the short term. The workshop ended with an informal get-together and snacks in the restaurant of the University Centre. 
We had personally invited the 28 interviewees from our research project and publicly invited all other community members from Vent and Obergurgl by leaflets and e-mails. A total of 28 local community members participated in the workshop, 25 of them were from the village of Obergurgl, only 3 from Vent. We suggest that it was not only the location that favoured the higher participation from community members of Obergurgl, but also their serious concerns about the resilience of the village, which is currently under great pressure from the Covid-19 pandemic. Through participating in the workshop, community members gathered information for future decisions on the development strategies of their villages, they entered into dialogue with other community members, and they were able to give feedback on the scientific results. All in all, the feedback for the workshop was positive and since participants kept up lively discussions on how to enhance resilience in their villages, we feel that we have achieved the overall goal of the workshop.

\subsection{International advisory board}

We installed an advisory board of a panel of national and international scientists, who contribute highlevel expertise from various geographical, conceptual and disciplinary backgrounds. Research experiences of other European countries and regions allow comparisons with other areas. This interaction was expected to provide opportunities for joint comparative publications. At the beginning of the project, this panel of experts gave first written or oral recommendations on a comprehensive literature review which helped us to refine the operationalization of the initial steps. The first workshop of the international advisory board was to discuss initial results, at the end of the project, the same scientific experts discussed the results in a wider context.

The first workshop was organized in February 2018. Over two days, the workshop with all members of the international advisory board, i.e., Ika Darnhofer (Institute of Agricultural and Forestry Economics at the University of Natural Resources and Life Sciences in Vienna, AT), Magnar Forbod (Center for Rural Research, Trondheim, NO), Johannes Rüdisser (University of Innsbruck, Institute of Ecology, AT), Markus Schermer (University of Innsbruck, Department of Sociology, AT), Geoff Wilson (University of Plymouth, School of Geography, Earth and Environmental Sciences, UK) and Karin Zbinden (School of Agricultural, Forest and Food Sciences, Department of Rural Sociology of Bern University of Applied Sciences, $\mathrm{CH}$ ), took place at the SoWi campus, University of Innsbruck. The previously forwarded literature report as well as the planned approaches within the single work packages were discussed. The advice and recommendations from the advisory board were very helpful for the further progress in our work.

The second workshop of the international advisory board was planned for April 2020, but because of the corona pandemic it was not possible to welcome the international experts at that time. We decided to focus on a shortened semi-virtual event, where the international members joined the local experts and the project team via video conference in late June. Participants were, again, Ika Darnhofer, Magnar Forbod, Johannes Rüdisser, Markus Schermer, Geoff Wilson and Karin Zbinden. We presented the disciplinary results of the project to them, but the main aim of the workshop was the presentation of the draft of the interdisciplinary paper and its subsequent discussion. The participants made valuable comments on the interdisciplinary paper, which we could include for the first submission of the manuscript:

Karin Zbinden: "[...] I hope you can motivate yourselves to deepen the conceptual aspects of your framework, integrating the context as well as an assessment of the value it has in different fields you touch in your study." 
Markus Schermer: "I think you should not (only) aim to compare the resilience of the two villages in quantitative/numerical terms, but rather discuss the most important factors for future resilience in dependence of the chosen development pathway. This might contribute more generally to the debate on the future of remote Alpine villages."

Geoff Wilson: "Discuss the various possibilities re reframing the paper we discussed, based on either a theoretical piece followed by an empirical piece, or strengthening the assessment/critique of your new suggested model through a stronger and more reflexive conclusion and analysis section."

The overall evaluation of the project was very positive, and especially the interdisciplinarity was highly praised by all participants of the international advisory board:

Johannes Rüdisser: "The truly interdisciplinary methodological approach led to very interesting and valuable results."

Karin Zbinden: "I like how you link the different and diverse aspects of the topic to tell a 'whole story' about your study context."

Magnar Forbod: "The strengths (the innovative potential...) of the project lie [...] in (1) the attempt to combine two scientific fields (ecology and social science), and on this basis (2) investigate two connected and highly relevant cases (in time and space)."

\subsection{Cooperation with touRES}

Two projects of the University of Innsbruck were funded by the Austrian Academy of Sciences within the 2015 call of the Earth System Sciences (ESS) research program. In addition to the project RESULT, it was the second project, touRES - Resilience of tourism systems to natural hazards in the Himalayas. investigated resilience of touristic entrepreneurs to natural hazards in Nepal. Members of both research projects (RESULT and touRES) took part in a series of self-moderated group discussions explaining their own theoretical approach to resilience and afterwards its implementation in the research process and the results gained. The common findings are presented in 4.5. Moreover, members of the two projects shared their experience of natural hazards modelling and mapping, and jointly supervised the master thesis "Natural hazard and protection forest modelling in Nepal Himalaya" by Moritz Waas. 
Adger, W. Neil (2000): Social and ecological resilience. Are they related? In: Progress in Human Geography 24 (3), S. 347-364. DOI: 10.1191/030913200701540465.

Allen, Mike (2017): Narrative Interviewing. In: Mike Allen (Hg.): The SAGE Encyclopedia of Communication Research Methods. 2455 Teller Road, Thousand Oaks California 91320: SAGE Publications, Inc.

Andexlinger, Wolfgang (2015): Alpine Urbanisierung. Transformation räumlicher Strukturen in Tirol. Habilitationsschrift. Universität Innsbruck, Innsbruck.

Anthopoulou, Theodosia; Melissourgos, Yorgos (2013): Agri-tourism In between rural change, tourism restructuring and environmental imperatives. In: Andrew Holden und David A. Fennell (Hg.): The Routledge handbook of tourism and the environment. London, New York: Routledge, S. 359-370.

Arriaza, M.; Cañas-Ortega, J. F.; Cañas-Madueño, J. A.; Ruiz-Aviles, P. (2004): Assessing the visual quality of rural landscapes. In: Landscape and Urban Planning 69 (1), S. 115-125. DOI: 10.1016/j.landurbplan.2003.10.029.

Bauerhansl, Christoph; Berger, Frederic; Dorren, Luuk; Duc, Philippe; Ginzler, Christian; Kleemayr, Karl et al. (2010): Development of harmonized indicators and estimation procedures for forests with protective functions against natural hazards in the alpine space. Hg. v. JRC Scientific and Technical Report. Institute for Environment and Sustainability (Joint Research Centre). Luxembourg.

Berger, F.; Larcher, V.; Simoni, S.; Pasquazzo, R.; Strada, C.; Zampredi, G. (2012): PARAmount WP6 guidelines - Rockfall and Forecast systems.

Bianchi, Rosella (2011): From agricultural to rural: agritourism as a productive option. In: Katia Laura Sidali, Achim Spiller und Birgit Schulze (Hg.): Food, Agri-Culture and Tourism. Linking Local Gastronomy and Rural Tourism: Interdisciplinary Perspectives. Berlin, Heidelberg: Springer-Verlag Berlin Heidelberg, S. 56-71.

Bogner, Alexander; Littig, Beate; Menz, Wolfgang (2014): Interviews mit Experten. Eine praxisorientierte Einführung. Wiesbaden: Springer Fachmedien Wiesbaden (Qualitative Sozialforschung). Online, http://dx.doi.org/10.1007/978-3-531-19416-5, last downloaded 2020-11-8.

Bohle, Hans-Georg; Etzold, Benjamin; Keck, Markus (2009): Resilience as Agency. In: IHDP update (2), S. 8-13.

Bristow, Gillian; Healy, Adrian (2014): Regional resilience: An agency perspective. In: Regional Studies 48 (5), S. 923-935. DOI: 10.1080/00343404.2013.854879.

Bürgi, Matthias; Silbernagel, Janet; Wu, Jianguo; Kienast, Felix (2015): Linking ecosystem services with landscape history. In: Landscape Ecol 30 (1), S. 11-20. DOI: 10.1007/s10980-014-0102-3.

Burton, Rob; Wilson, Geoff (2012): The Rejuvenation of productivist Agriculture. The Case for 'cooperative Neo-Productivism'. In: Reidar Almås und Hugh Campbell (Hg.): Rethinking agricultural policy regimes. Food security, climate change and the future resilience of global agriculture. 1. ed. Bingley, U.K: Emerald (Research in rural sociology and development, 18), S. 51-72.

Carney, Diana; Drinkwater, Michael; Rusinow, Tamara; Neefjes, Koos; Wanmali, Samir; Singh, Naresh (1999): LIVELIHOODS APPROACHES COMPARED. A brief comparison of the livelihoods approaches of the UK. Department for International Development.

Che, Deborah; Veeck, Gregory; Veeck, Ann (2005): Agritourism and the selling of local food production, family and rural American traditions to maintain family farming heritage. In: A. J. Essex, A. W. Gilg und R. B. Yarwood (Hg.): Rural Change and Sustainability. Agriculture, The Environment and Communities. Wallingford: CABI. 
Costanza, Robert; Groot, Rudolf de; Sutton, Paul; van der Ploeg, Sander; Anderson, Sharolyn J.; Kubiszewski, Ida et al. (2014): Changes in the global value of ecosystem services. In: Global Environmental Change 26, S. 152-158. DOI: 10.1016/j.gloenvcha.2014.04.002.

Cote, Muriel; Nightingale, Andrea J. (2012): Resilience thinking meets social theory: Situating social change in socio-ecological systems (SES) research. In: Progress in Human Geography 36 (4), S. 475489. DOI: $10.1177 / 0309132511425708$.

Darnhofer, I. (2014): Resilience and why it matters for farm management. In: European Review of Agricultural Economics 41 (3), S. 461-484. DOI: 10.1093/erae/jbu012.

Darnhofer, Ika; Lamine, Claire; Strauss, Agnes; Navarrete, Mireille (2016): The resilience of family farms. Towards a relational approach. In: Journal of Rural Studies 44, S. 111-122. DOI: 10.1016/j.jrurstud.2016.01.013.

Davidson, Debra J. (2010): The Applicability of the Concept of Resilience to Social Systems. Some Sources of Optimism and Nagging Doubts. In: Society \& Natural Resources 23 (12), S. 1135-1149. DOI: 10.1080/08941921003652940.

Davoudi, Simin; Shaw, Keith; Haider, L. Jamila; Quinlan, Allyson; Peterson, Garry D.; Wilkinson, Cathy et al. (2012): Resilience: A Bridging Concept or a Dead End? "Reframing" Resilience: Challenges for Planning Theory and Practice Interacting Traps: Resilience Assessment of a Pasture Management System in Northern Afghanistan Urban Resilience: What Does it Mean in Planning Practice? Resilience as a Useful Concept for Climate Change Adaptation? The Politics of Resilience for Planning: A Cautionary Note. In: Planning Theory and Practice 13 (2), S. 299-333. DOI: 10.1080/14649357.2012.677124.

DeVerteuil, Geoff; Golubchikov, Oleg (2016): Can resilience be redeemed? In: City 20 (1), S. 143-151. DOI: 10.1080/13604813.2015.1125714.

Dominati, Estelle; Patterson, Murray; Mackay, Alec (2010): A framework for classifying and quantifying the natural capital and ecosystem services of soils. In: Ecological Economics 69 (9), S. 1858-1868. DOI: 10.1016/j.ecolecon.2010.05.002.

Dorward, Andrew R. (2014): Livelisystems: a conceptual framework integrating social, ecosystem, development, and evolutionary theory. In: E\&S 19 (2). DOI: 10.5751/ES-06494-190244.

Egarter Vigl, Lukas; Tasser, Erich; Schirpke, Uta; Tappeiner, Ulrike (2017): Using land use/land cover trajectories to uncover ecosystem service patterns across the Alps. In: Reg Environ Change 17 (8), S. 2237-2250. DOI: 10.1007/s10113-017-1132-6.

Egger, Gregory; Angermann, Karoline; Aigner, Susanne; Buchgraber, Karl (2004): GIS-gestützte Ertragsmodellierung zur Optimierung des Weidemanagements auf Almweiden.

Emery, Mary; Flora, Cornelia (2006): Spiraling-Up. Mapping Community Transformation with Community Capitals Framework. In: Community Development 37 (1), S. 19-35. DOI: 10.1080/15575330609490152.

European Environment Agency (2015a): European inventory of nationally designated areas. Online, https://www.eea.europa.eu/data-and-maps/data/nationally-designated-areas-nationalcdda-10, last downloaded 2016-10-21.

European Environment Agency (2015b): Natura 2000 data - the European network of protected sites.

European Environment Agency (2016a): Corine Land Cover 2012. Kopenhagen, Denmark. Online, http://land.copernicus.eu/pan-european/corine-land-cover/clc-2012, last downloaded 2020-1108.

European Environment Agency (2016b): EU-Hydro River Network 2016. Dataset. Online, https://land.copernicus.eu/pan-european/satellite-derived-products/eu-hydro/eu-hydro-publicbeta/eu-hydro-river-network/view, last downloaded 2020-10-01. 
European Environment Agency (2016c): European Digital Elevation Model (EU-DEM), version 1.0. Dataset. Online, http://land.copernicus.eu/pan-european/satellite-derived-products/eu-dem/eudem-, last downloaded 2020-10-01.

Fecht, Michael; Höfle, Bernhard; Starnberger, Reinhard; Kaser, Georg (2005): Eine Karte der aktuellen Verdunstung für das Tirol Atlas Gebiet anhang von Landnutzungs- und Vegetationsdaten. Institut für Geographie, Universität Innsbruck. Online, https://tirolatlas.uibk.ac.at/topics/water/pub/evaporation.pdf, last downloaded 2020-10-01.

Fick, Stephen E.; Hijmans, Robert J. (2017): WorldClim 2: New 1-Km Spatial Resolution Climate Surfaces for Global Land Areas. In: International Journal of Climatology (37), S. 4302-4315. DOI: 10.1002/joc.5086.

Flanigan, Sharon; Blackstock, Kirsty; Hunter, Colin (2014): Agritourism from the perspective of providers and visitors. A typology-based study. In: Tourism Management 40, S. 394-405. DOI: 10.1016/j.tourman.2013.07.004.

Fleischer, Aliza; Tchetchik, Anat (2005): Does rural tourism benefit from agriculture? In: Tourism Management 26 (4), S. 493-501. DOI: 10.1016/j.tourman.2003.10.003.

Flury, Christian; Huber, Robert; Tasser, Erich (2013): Future of Mountain Agriculture in the Alps. In: Stefan Mann (Hg.): The Future of Mountain Agriculture. Berlin, Heidelberg: Springer (Springer Geography), S. 105-126.

Folke, Carl (2006): Resilience. The emergence of a perspective for social-ecological systems analyses. In: Global Environmental Change 16 (3), S. 253-267. DOI: 10.1016/j.gloenvcha.2006.04.002.

Folke, Carl, Carpenter, Stephen R.; Walker, Brian; Scheffer, Marten; Chapin, Terry; Rockström, Johan (2010): Resilience Thinking. Integrating Resilience, Adaptability and Transformability. In: Ecology and Society 15 (4).

Footprints (2007): MaB Biosphärenpark Ötztal. Endbericht Phase 1.

Footprints (2008): MaB Biosphärenpark Ötztal. Endbericht Phase 2.

Freshwater, David (2015): Vulnerability and Resilience. Two Dimensions of Rurality. In: Sociol Ruralis 55 (4), S. 497-515. DOI: 10.1111/soru.12090.

Gardner, James S.; Dekens, Julie (2007): Mountain hazards and the resilience of social-ecological systems: lessons learned in India and Canada. In: Natural Hazards, S. 317-336. DOI: 10.1007/s11069006-9038-5.

George, E. Wanda; Reid, Donald G.; Mair, Heather (2009): Rural tourism development. Localism and cultural change. Bristol: Channel View Publications (Tourism and cultural change, 17). Online, http://search.ebscohost.com/login.aspx?di-

rect=true $\&$ scope $=s i t e \& d b=n l e b k \& d b=$ nlabk\&AN=272943, last downloaded 2016-10-21.

Groot, Rudolf S. de; Wilson, Matthew A.; Boumans, Roelof M. J. (2002): A typology for the classification, description and valuation of ecosystem functions, goods and services. In: Ecological Economics 41 (3), S. 393-408. DOI: 10.1016/S0921-8009(02)00089-7.

Gruber, C. (2019): Landschaft im oberen Ötztal: Wandel - Wahrnehmung - Wertschätzung. University of Innsbruck, Innsbruck.

Häder, Michael (2010): Empirische Sozialforschung. 2., überarbeitete Auflage. Wiesbaden: VS Verl. für Sozialwiss. Online verfügbar unter http://dx.doi.org/10.1007/978-3-531-92187-7.

Haines-Young, Roy; Potschin, Marion (2018): Common International Classification of Ecosystem Services (CICES) V5.1. Guidance on the Application of the Revised Structure. Online, https://cices.eu/content/uploads/sites/8/2018/01/Guidance-V51-01012018.pdf, last downloaded 2020-11-08. 
Hall, C. Michael (2010): Tourism and biodiversity: more significant than climate change? In: Journal of Heritage Tourism 5 (4), S. 253-266. DOI: 10.1080/1743873X.2010.517843.

Hall, Colin Michael; Page, Stephen (2006): The geography of tourism and recreation. Environment, place and space. 3. ed. London: Routledge (Geography and tourism). Online, http://www.loc.gov/catdir/enhancements/fy0653/2004028639-d.html, last downloaded 2020-1108.

Hassan, Rashid; Scholes, Robert; Ash, Neville (Hg.) (2005): Ecosystems and Human Well-being:Current State and Trends. Millenium Ecosystem Assessment. Volume 1. Washington: Island Press.

Haßlacher, Peter (2004): Morgenröte für Vent im Ötztal? Tourismuspolitische Entwicklungsperspektiven. In: Louis Oberwalder (Hg.): Franz Senn. Alpinismuspionier und Gründer des Alpenvereins. Innsbruck, Wien: Tyrolia-Verl., S. 178-191.

Hess, Heinrich (1894): Die Oetzthaler Gruppe. In: Eduard Richter (Hg.): Die Erschließung der Ostalpen : 2. Die Centralalpen westlich vom Brenner. Berlin: Verlag des. Deutschen und Öesterreichischen Alpenvereins, S. 245-377.

Hobsbawm, Eric J.; Ranger, T. O. (Hg.) (2012): The Invention of tradition. Cambridge: Cambridge University Press (Canto classics). Online, https://doi.org/10.1017/CBO9781107295636, last downloaded 2020-11-08.

Holling, C. S. (2001): Understanding the Complexity of Economic, Ecological, and Social Systems. In: Ecosystems 4 (5), S. 390-405. DOI: 10.1007/s10021-001-0101-5.

Hosseini, Seyedmohsen; Barker, Kash; Ramirez-Marquez, Jose E. (2016): A review of definitions and measures of system resilience. In: Reliability Engineering \& System Safety (145), S. 47-61. DOI: 10.1016/j.ress.2015.08.006.

Huber, Lisa; Posch, Eva Luise; Höferl, Karl Michael; Bell, Rainer; Stotten, Rike; Tasser, Erich et al. (submitted): Two Perspectives - one Goal: Resilience Research in Protected Mountain Regions. In: Ecomont.

Huber, Lisa; Schirpke, Uta; Marsoner, Thomas; Tasser, Erich; Leitinger, Georg (2020): Does socioeconomic diversification enhance multifunctionality of mountain landscapes? In: Ecosystem Services 44. DOI: 10.1016/j.ecoser.2020.101122.

Ingrisch, Johannes; Bahn, Michael (2018): Towards a Comparable Quantification of Resilience. In: Trends in Ecology \& Evolution 33 (4), S. 251-259. DOI: 10.1016/j.tree.2018.01.013.

Jarvis, Andrew; Guevara, Edward; Reuter, Hannes Isaak; Nelson, Andy (2008): Hole-Filled SRTM for the Globe Version 4. CGIAR-CSI SRTM 90 m Database. Online verfügbar unter http://srtm.csi.cgiar.org. Johnson, R. Burke; Onwuegbuzie, Anthony J.; Turner, Lisa A. (2007): Toward a Definition of Mixed Methods Research. In: Journal of Mixed Methods Research 1 (2), S. 112-133. DOI: 10.1177/1558689806298224.

Kelly, Claire; Ferrara, Agostino; Wilson, Geoff A.; Ripullone, Francesco; Nolè, Angelo; Harmer, Nichola; Salvati, Luca (2015): Community resilience and land degradation in forest and shrubland socio-ecological systems. Evidence from Gorgoglione, Basilicata, Italy. In: Land Use Policy 46, S. 11-20. DOI: 10.1016/j.landusepol.2015.01.026.

Klebinder, Klaus; Fromm, Reinhard; Perzl, Frank (2009): Ausweisung von Lawinenschutzwald mittels GIS und einfachen Modellrechnungen. In: Josef Strobl, Thomas Blaschke und Gerald Griesebner (Hg.): Angewandte Geoinformatik 2012. Beiträge zum 21. AGIT Symposium Salzburg. Heidelberg: Wichmann, S. 94-103. Online, http://www.agit.at/s_c/papers/2009/7555.pdf, last downloaded 2020-10-11. 
Konopásek, Zdenek (2011): Das Denken mit ATLAS.ti sichtbar machen: Computergestützte qualitative Analyse als textuelle Praxis. In: G. Nter Mey und Katja Mruck (Hg.): Grounded Theory Reader. Wiesbaden: Springer Fachmedien, S. 381-403.

Küsters, Ivonne (2009): Narrative Interviews. Grundlagen und Anwendungen. 2. Auflage. Wiesbaden: VS Verlag für Sozialwissenschaften / GWV Fachverlage $\mathrm{GmbH}$ Wiesbaden. Online, http://dx.doi.org/10.1007/978-3-531-91440-4, last downloaded 2020-11-08.

Lavorel, Sandra; Grigulis, Karl; Lamarque, Pénélope; Colace, Marie-Pascale; Garden, Denys; Girel, Jacky et al. (2011): Using plant functional traits to understand the landscape distribution of multiple ecosystem services. In: Journal of Ecology 99 (1), S. 135-147. DOI: 10.1111/j.1365-2745.2010.01753.x. Lavorel, Sandra; Grigulis, Karl; Leitinger, Georg; Kohler, Marina; Schirpke, Uta; Tappeiner, Ulrike (2019): Historical trajectories in land use pattern and grassland ecosystem services in two European alpine landscapes. In: Reg Environ Change 17 (8), S. 2251-2264. DOI: 10.1007/s10113-017-1207-4.

Lobao, Linda; Sharp, Jeff (2014): Agriculture and rural development. In: G. P. Green (Hg.): Handbook of Rural Development. Cheltenham: Edward Elgar Publishing (Elgar original reference).

López-i-Gelats, Feliu (2013): is Mountain Farming No Longer Viable? The Complex Dynamics of Farming Abandonment in the Pyrenees. In: Stefan Mann (Hg.): The Future of Mountain Agriculture. Berlin, Heidelberg: Springer (Springer Geography), S. 89-104.

Markantoni, Marianna; Strijker, Dirk; Koster, Sierdjan (2014): Motives for starting up a side activity in rural areas in the Netherlands. In: Local Economy 29 (6-7), S. 723-739. DOI: $10.1177 / 0269094214552947$.

Mayring, Philipp (2007): Qualitative Inhaltsanalyse. Grundlagen und Techniken. 9. Aufl. Weinheim u.a.: Beltz (UTB, 8229).

Meixner, Wolfgang (2006): Tourismus. In: Roland Psenner und Reinhard Lackner (Hg.): Die Alpen im Jahr 2020. [interdisziplinärer Dialog, Oktober 2005 im Universitätszentrum Obergurgl]. 1. Aufl. Innsbruck: Innsbruck Univ. Press (Alpine space, 1), S. 57-67.

Meixner, Wolfgang; Rieder, Elisabeth; Schermer, Markus (2010): Von der Sommerfrische zum Agrotourismus. Die Auswirkungen von Urlaub am Bauernhof auf Lebens- und Arbeitsverhältnisse auf Tiroler Bauernhöfen. In: Rita Garstenauer, Erich Landsteiner und Langthaler (Hg.): Land-Arbeit. Arbeitsbeziehungen in ländlichen Gesellschaften Europas (17. bis 20. Jahrhundert). Innsbruck: Studien-Verl. (Jahrbuch für Geschichte des ländlichen Raumes, 2008), S. 219-229.

Meleghy, Tamás; Preglau, Max; Tafertshofer, Alois (1980): Sozialstruktur einer Fremdenverkehrsgemeinde. Am Beispiel Obergrurgl, Vent und Zwieselstein. Hg. v. Universität Innsbruck. Institut für Soziologie. Innsbruck.

Meleghy, Tamás; Preglau, Max; Tafertshofer, Alois (1985): Tourism development and value change. In: Annals of Tourism Research 12 (2), S. 181-199. DOI: 10.1016/0160-7383(85)90056-8.

Millenium Ecosystem Assessment (2005): Ecosystems and Human Well-being: Synthesis. Washington, DC.

Ministry of Sustainability and Tourism (2019): Grüner Bericht 2019. Die Situation der österreichischen Land- und Forstwirtschaft. Wien. Online, https://gruenerbericht.at/cm4/jdownload/send/2-gr-bericht-terreich/2007-gb2019, last downloaded 2008-04-20.

Mitchell, Morag; Hall, Derek R. (2005): Rural Tourism as Sustainable Business. Key Themes and Issues. In: Derek R. Hall, Irene Kirkpatrick und Morag Mitchell (Hg.): Rural tourism and sustainable business. Clevedon UK, Buffalo: Channel View Publications (Aspects of tourism, 26), S. 3-14.

Mountain Villages. Online, http://www.mountainvillages.at/, last downloaded 2016-03-29. 
Nettier, Baptiste; Dobremez, Laurent; Lavorel, Sandra; Brunschwig, Gilles (2017): Resilience as a framework for analyzing the adaptation of mountain summer pasture systems to climate change. In: Ecology and Society 22 (4). DOI: 10.2307/26799004.

Oberwalder, Louis (Hg.) (2004): Franz Senn. Alpinismuspionier und Gründer des Alpenvereins. Innsbruck, Wien: Tyrolia-Verl.

OECD (1994): TOURISM STRATEGIES AND RURAL DEVELOPMENT. Paris. Online, http://www.oecd.org/cfe/tourism/2755218.pdf, last downloaded 2016-02-02.

Paier, Dietmar (2010): Quantitative Sozialforschung. Eine Einführung. 1. Aufl. Wien: Facultas.WUV.

Patzelt, Gernot (Hg.) (1989): 1889-1989. 100 Jahre Edelweiss. Die Geschichte des Hotels 'Edelweiss \& Gurgl' in Obergurgl, Ötztal, Tirol: Eigenverlag Erich Scheiber.

Phillip, Sharon; Hunter, Colin; Blackstock, Kirsty (2010): A typology for defining agritourism. In: Tourism Management 31 (6), S. 754-758. DOI: 10.1016/j.tourman.2009.08.001.

Pinzer, Beatrix; Pinzer, Egon (1998): Ötztal. Landschaft, Kultur, Erholungsraum. Innsbruck: Ed. Löwenzahn.

Power, A. G. (2010): Ecosystem services and agriculture. Tradeoffs and synergies. In: Philosophical Transactions of the Royal Society B: Biological Sciences 365 (1554), S. 2959-2971. DOI: 10.1098/rstb.2010.0143.

Preglau, Max; Meleghy, Tamás; Frantz, Klaus; Tafertshofer, Alois (1985): Fremdenverquer. Kosten und Nutzen des Tourismus am Beispiel Obergurgl. 1. Aufl. Innsbruck (Schriftenreihe der Michael-Gaismair-Gesellschaft, 4).

Przyborski, Aglaja; Wohlrab-Sahr, Monika (2009): Qualitative Sozialforschung. Ein Arbeitsbuch. 2., korr. Aufl. München: Oldenbourg (Lehr- und Handbücher der Soziologie).

Renting, Henk; Oostindie, Henk; Laurent, Catherine; Brunori, Gianluca; Barjolle, Dominique; Jervell, Anne Moxnes et al. (2008): Multifunctionality of agricultural activities, changing rural identities and new institutional arrangements. In: IJARGE 7 (4/5), S. 361. DOI: 10.1504/IJARGE.2008.020083.

Rickards, L.; Howden, S. M. (2012): Transformational adaptation. Agriculture and climate change. In: Crop Pasture Sci. 63 (3), S. 240. DOI: 10.1071/CP11172.

Schermer, Markus (1989): Entwicklungsmöglichkeiten fürv die bäuerliche Landiwrtschaft am Beispiel Tirol. In: Gaby Regenermel und Michael Schmid (Hg.): NEULAND. Die Wiederentdeckung bäuerlicher Direktvermarktung. Wien: Herold, S. 44-55.

Schermer, Markus; Darnhofer, Ika; Daugstad, Karoline; Gabillet, Marine; Lavorel, Sandra; Steinbacher, Melanie (2016): Institutional impacts on the resilience of mountain grasslands. An analysis based on three European case studies. In: Land Use Policy 52, S. 382-391. DOI: 10.1016/j.landusepol.2015.12.009.

Schirpke, Uta (2011): GIS-gestützte Ausweisung potenzieller Trockenzonen in Südtirol. Hg. v. Eurac Research. Bozen.

Schirpke, Uta; Altzinger, Andreas; Leitinger, Georg; Tasser, Erich (2019): Change from agricultural to touristic use: Effects on the aesthetic value of landscapes over the last 150 years. In: Landscape and Urban Planning 187, S. 23-35. DOI: 10.1016/j.landurbplan.2019.03.004.

Schirpke, Uta; Leitinger, Georg; Tasser, Erich; Schermer, Markus; Steinbacher, Melanie; Tappeiner, UIrike (2013a): Multiple ecosystem services of a changing Alpine landscape. Past, present and future. In: International Journal of Biodiversity Science, Ecosystem Services \& Management 9 (2), S. 123 135. DOI: $10.1080 / 21513732.2012 .751936$.

Schirpke, Uta; Meisch, Claude; Marsoner, Thomas; Tappeiner, Ulrike (2018): Revealing spatial and temporal patterns of outdoor recreation in the European Alps and their surroundings. In: Ecosystem Services 31, S. 336-350. DOI: 10.1016/j.ecoser.2017.11.017. 
Schirpke, Uta; Tasser, Erich; Tappeiner, Ulrike (2013b): Predicting scenic beauty of mountain regions. In: Landscape and Urban Planning, S. 1-12.

Schirpke, Uta; Timmermann, Florian; Tappeiner, Ulrike; Tasser, Erich (2016): Cultural ecosystem services of mountain regions: Modelling the aesthetic value. In: Ecological Indicators, S. 78-90. DOI: 10.1016/j.ecolind.2016.04.001.

Schmid, Christian (2005): Stadt, Raum und Gesellschaft. Henri Lefebvre und die Theorie der Produktion des Raumes. Stuttgart: Steiner (Sozialgeographische Bibliothek, 1).

Scoones, Ian (1998): Sustainable rural livelihoods. A framework for analysis. IDS working paper 72. Institute of Development Studies.

Scoones, Ian (2009): Livelihoods perspectives and rural development. In: The Journal of Peasant Studies 36 (1), S. 171-196. DOI: 10.1080/03066150902820503.

Sharpley, Richard; Vass, Adrian (2006): Tourism, farming and diversification. An attitudinal study. In: Tourism Management 27 (5), S. 1040-1052. DOI: 10.1016/j.tourman.2005.10.025.

Sidali, Katia Laura; Kastenholz, Elisabeth; Bianchi, Rossella (2013): Food tourism, niche markets and products in rural tourism. Combining the intimacy model and the experience economy as a rural development strategy. In: Journal of Sustainable Tourism 23 (8-9), S. 1179-1197. DOI: 10.1080/09669582.2013.836210.

Spellerberg, Ian F.; Fedor, Peter J. (2003): A tribute to Claude Shannon (1916-2001) and a plea for more rigorous use of species richness, species diversity and the 'Shannon-Wiener' Index. In: Global Ecology and Biogeography 12 (3), S. 177-179. DOI: 10.1046/j.1466-822X.2003.00015.x.

STATISTIK AUSTRIA (2017): Statistik des Bevölkerungsstandes, 23.05.2017. Online, http://www.statistik.at/wcm/idc/idcplg?IdcService=GET_NATIVE_FILE\&RevisionSelectionMethod=LatestReleased\&dDocName=103419, last downloaded 2017-07-06.

Stotten, Rike (2020a): The role of farm diversification and peasant habitus for farm resilience in mountain areas: the case of the Ötztal valley, Austria. In: International Journal of Social Economics. DOI: 10.1108/IJSE-12-2019-0756.

Stotten, Rike (2020b): Tourismuseinwirkungen auf zwei Dörfer mit unterschiedlichen Entwicklungspfaden: Vent und Obergurgl (Tirol). In: Jahrbuch für Geschichte des ländlichen Raumes. (forthcoming)

Stotten, Rike; Schermer, Markus; Wilson, Geoff (submitted a): Lock-ins and community resilience: the example of two contrasting trajectories in the Austrian Alp.s In: Journal of Rural Studies

Stotten, Rike; Huber, Lisa; Tasser, Erich; Leitinger, Georg (submitted b): Social-ecological resilience in remote mountain communities: towards a novel framework for an interdisciplinary investigation. In: Ecology and Society.

Stotten, Rike; Maurer, Michaela; Herrmann, Hannes; Schermer, Markus (2019): Different Forms of Accommodation in Agritourism: The Role of Decoupled Farmer-Based Accommodation in the Ötztal Valley (Austria). In: Sustainability 11 (10), S. 2841. DOI: 10.3390/su11102841.

Streifeneder, Thomas (2016): Agriculture first. Assessing European policies and scientific typologies to define authentic agritourism and differentiate it from countryside tourism. In: Tourism Management Perspectives 20, S. 251-264. DOI: 10.1016/j.tmp.2016.10.003.

Stürck, Julia; Verburg, Peter H. (2017): Multifunctionality at what scale? A landscape multifunctionality assessment for the European Union under conditions of land use change. In: Landscape Ecol 32 (3), S. 481-500. DOI: 10.1007/s10980-016-0459-6.

Sulzer, Ulrike (2018): Einfluss der Sozio-Ökonomie auf die Entwicklung der Landschaft in den Fraktionen der Gemeinde Sölden. Diplomarbeit. University of Innsbruck, Innsbruck.

Taff; Benfield; Miller; D'Antonio; Schwartz (2019): The Role of Tourism Impacts on Cultural Ecosystem Services. In: Environments 6 (4), S. 43. DOI: 10.3390/environments6040043. 
Tasser, Erich; Ruffini, Flavio V.; Tappeiner, Ulrike (2009): An integrative approach for analysing landscape dynamics in diverse cultivated and natural mountain areas. In: Landscape Ecol 24 (5), S. 611628. DOI: 10.1007/s10980-009-9337-9.

Tasser, Erich; Schirpke, Uta; Zoderer, Brenda Maria; Tappeiner, Ulrike (2020): Towards an integrative assessment of land-use type values from the perspective of ecosystem services. In: Ecosystem Services 42, S. 101082. DOI: 10.1016/j.ecoser.2020.101082.

Tasser, Erich; Sternbach, Elisabeth; Tappeiner, Ulrike (2008): Biodiversity indicators for sustainability monitoring at municipality level: An example of implementation in an alpine region. In: Ecological Indicators 8 (3), S. 204-223. DOI: 10.1016/j.ecolind.2007.01.005.

Telfer, David (2015): Tourism and Regional Development Issues. In: Richard Sharpley und David Telfer (Hg.): Tourism and development. Concepts and issues. 2. ed. Bristol u.a.: Channel View Publ (Aspects of tourism, 63), S. 140-177.

Tew, Christine; Barbieri, Carla (2012): The perceived benefits of agritourism. The provider's perspective. In: Tourism Management 33 (1), S. 215-224. DOI: 10.1016/j.tourman.2011.02.005.

Van Der Ploeg, Jan Douwe (2009): The new peasantries. Struggles for autonomy and sustainability in an era of empire and globalization. Repr. der Ausg. 2008. London: Earthscan.

Van Der Ploeg, Jan Douwe; Renting, Henk; Brunori, Gianluca; Knickel, Karlheinz; Mannion, Joe; Marsden, Terry et al. (2000): Rural Development: From Practices and Policies towards Theory. In: Sociologia Ruralis 40 (4), S. 391-408.

Voigt, S. (2013): Der Schutzwald im Alpenraum - Länderübergreifende Harmonisierung der Abrenzungskritierien für die Schutzwald-ausweisung und deren GIS-gestützte Modellierung und Verortung. Universität Salzburg, Salzburg.

Voinov, Alexey; Bousquet, Francois (2010): Modelling with stakeholders. In: Environmental Modelling and Software 25 (11), S. 1268-1281. DOI: 10.1016/j.envsoft.2010.03.007.

Walker, Brian; Holling, C.; Carpenter. Stephen; Kinzig, Ann (2004): Resilience, Adaptability and Transformability in Social-ecological Systems. In: Ecology and Society 9 (2).

Weiss, Christoph (1994): Do they come back again? The symmetry and reversibility of off-farm employment. In: European Review of Agricultural Economics 24, S. 65-84.

Weiß, Miriam L.; Hoffmann, Christian; Streifeneder, Thomas (2016): Cooperation Models and PluriActivity to Exhaust Value-Added Potentials in Mountain Regions. In: Boian Koulov und Georgi Zhelezov (Hg.): Sustainable mountain regions. Challenges and perspectives in Southeastern Europe, Bd. 30. Switzerland: Springer, S. 17-31.

Wieser, Gerhard; Hammerle, Albin; Wohlfahrt, Georg (2008): The water balance of grassland ecosystems in the Austrian Alps. In: Arctic, Antarctic, and Alpine Research 40 (2), S. 439-445. DOI: 10.1657/1523-0430(07-039)[WIESER]2.0.CO;2.

Wilson, Geoff (2001): From productivism to post-productivism ... and back again? Exploring the (un)changed natural and mental landscapes of European agriculture.

Wilson, Geoff (2010): Multifunctional 'quality' and rural community resilience. In: Transactions of the Institute of British Geographers 35 (3), S. 364-381. DOI: 10.1111/j.1475-5661.2010.00391.x.

Wilson, Geoff (2012a): Community resilience and environmental transitions. 1. Aufl. London: Routledge. doi=10.4324/9780203144916, last downloaded 2020-11-08.

Wilson, Geoff (2012b): Community resilience, globalization, and transitional pathways of decisionmaking. In: Geoforum 43 (6), S. 1218-1231. DOI: 10.1016/j.geoforum.2012.03.008.

Wipf, S.; Rixen, C.; Fischer, M.; Schmid, B.; Stoeckli, V. (2005): Effects of Ski Piste Preparation on Alpine Vegetation. In: Journal of Applied Ecology 42 (2), S. 306-316. 
Zimmermann, Patrick; Tasser, Erich; Leitinger, Georg; Tappeiner, Ulrike (2010): Effects of land-use and land-cover pattern on landscape-scale biodiversity in the European Alps. In: Agriculture, Ecosystems \& Environment 139 (1-2), S. 13-22. DOI: 10.1016/j.agee.2010.06.010.

Zucca, Michela (2006): The Alps. The People: Anthropology of Small Communities. Demographic Movements. Women's Condition. Development Perspectives. Centro di Ecologia Alpina. Trento, Italy (1). 
Appendix 


\title{
through synergies between agriculture and tourism for two contrasting trajectories in the Tyrolean Alps
}

\author{
Georg Leitinger ${ }^{1, *}$, Lisa Huber ${ }^{1}$, Erich Tasser ${ }^{2}$, Andreas Altzinger ${ }^{2}$, Hannes Herrmann ${ }^{3}$, Rike Stotten ${ }^{3}$ \\ ${ }^{1}$ Department of Ecology, University of Innsbruck, Austria; ${ }^{2}$ Institute for Alpine Environment, Eurac Research, Viale Druso 1, Bozen/Bolzano, Italy; \\ ${ }^{3}$ Department of Sociology, University of Innsbruck, Austria
}

\begin{abstract}
Context
The tourism industry contributes to the rural livelihood in Austrian mountain areas. Multifunctional farming has various ways to integrate with the tourism sector: providing accommodation in the form of on farm holidays, using employment opportunities as well as marketing opportunities for their products and gaining compensation for the provision of public goods and the use of their property by tourism operators.

The project explores the synergies provided by these interlinkages between agriculture and tourism on three different levels: First of all the effects on the resilience of family farms, second of the rural communities and last not least on their surrounding social-ecological system, measured by the provision of selected ecosystem services (ES).

The empirical case is provided by the two villages of Obergurgl and Vent, both parts of the municipality of Sölden in the Tyrolean Alps.
\end{abstract}

While Obergurgl is almost entirely focusing on winter tourism, Vent has positioned itself as a mountaineering village, with a stronger focus on the

- summer season.

\section{Objectives}

- Development of an interdisciplinary approach based on natural and social sciences to investigate interlinkages of farming and tourism:

- Verify the impact of these interlinkages on social-ecological, farm and community resilience

- Provision of a base for long-term development for preservation of landscape by modeling of ecosystem services (from history to current state)

\section{Sociological aspects}

The study highlights that both communities are facing substantial resilience challenges, however their vulnerability issues differ. On the one hand, Obergurgl is relying on its economic capital and drivers; its social capital (the cohesion of the community) has weakened with the structural change from a farming towards a service economy. Even if the remaining family farms are relatively resilient, their reputation within the community has lost dramatically. On the other hand, Vent is relying on its natural resources, valorizing its remote location and the agrarian landscape. The case studies under investigation demonstrate two different trajectories and different configurations of capitals to aim for resilience.

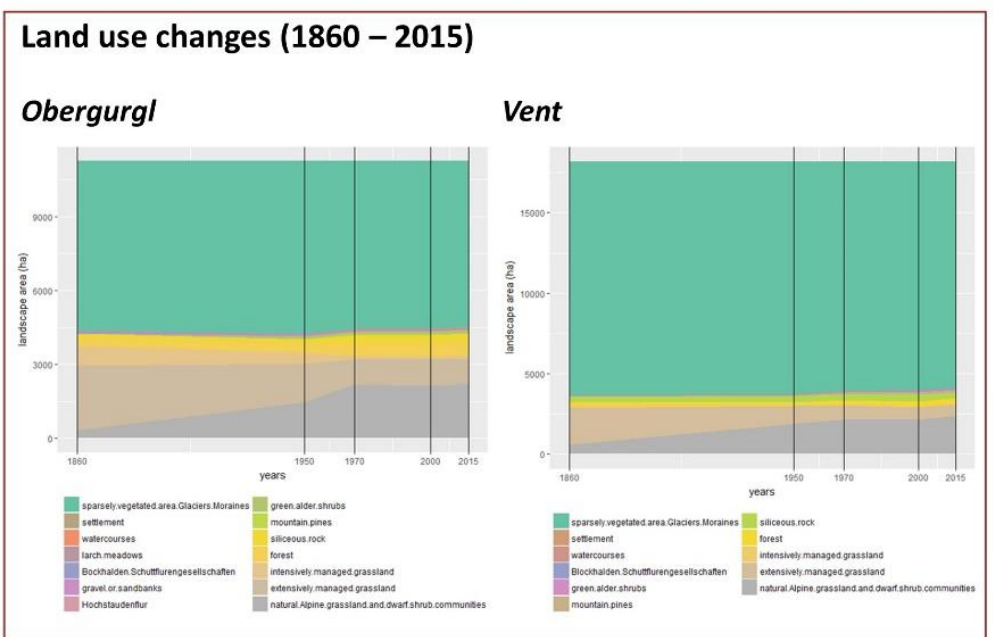

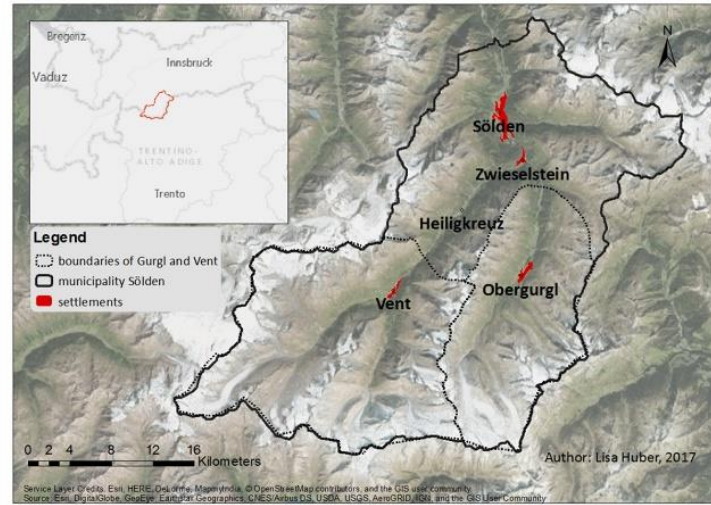

Importance of selected ecosystem services

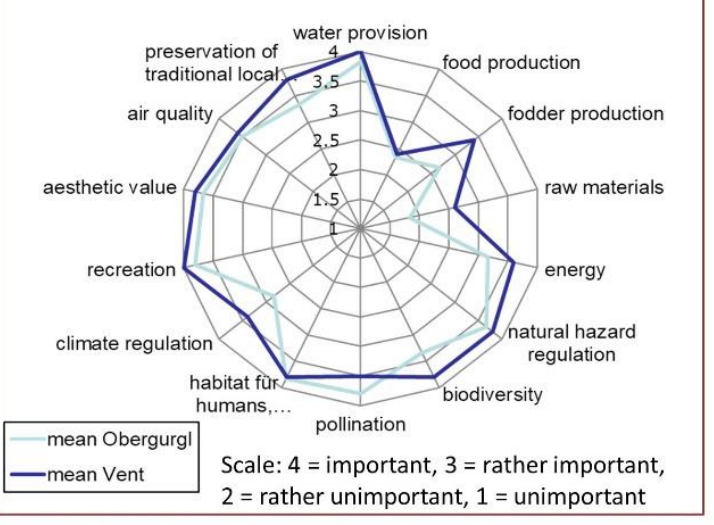

Landscape diversity

Shannon diversity (SHDI), Patch Number (PN) and Mean Patch Size (MPS). All variables are set to 1.0 $(100 \%)$ at the starting year 1860 .
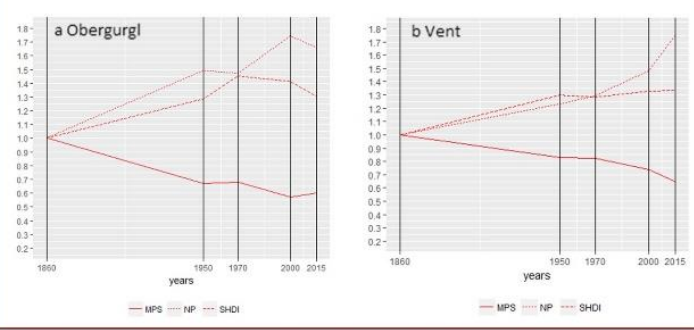

\section{Conclusion}

Through history the greatest landscape heterogeneity would be associated with the greatest diversity in ES

('multifunctionality'). While Obergurgl follows the general trend of the Alps (decreasing landscape diversity due to abandonment), Vent targets towards higher diversity. This is seen as a first evidence of higher resilience of ES provision. *contact: rike.stotten@uibk.ac.at georg.leitinger@uibk.ac.at

Department of Ecology Georg Leitinger, Lisa Huber
This project received funding from the Austrian Academy of Sciences (ÖAW) within the Earth System Science Call 2015, Project 'RESULT'
Department of Sociology Rike Stotten, Hannes Herrmann 


\title{
Community resilience in mountain areas: evidence of a qualitative approach in the Austrian Alps
}

\section{Forum ODT 2018 - Perspectives on Territories in Transition}

\author{
Stotten, Rike ${ }^{1}$; Herrmann, Hannes ${ }^{1}$ \\ ${ }^{1}$ University of Innsbruck, Department of Sociology
}

\begin{abstract}
Context
Building on critical community resilience studies (e.g. Sharifi 2016; Kelly et al. 2015), the conceptual framework of community resilience is based on social, cultural, economic, political and environmental capitals and drivers. Their configuration influence the resilience or vulnerability of a community (Emery and Flora 2006; Wilson 2012). To be resilient communities should have the capacity to buffer shocks and conserve existing functions and structures in the face of disturbances, should be able to reorganise and learn within the current system (adaptability) and should have the capacity to create a new trajectory rooted in radical change (transformability). Thus, resilient communities have a diversity of responses to remain stable (Wilson, 2012).

The two remote Alpine mountain communities, Obergurgl and Vent, in the Austrian Ötztal developed from livestock farming to tourism services as a main source for livelihood incomes. However, both are challenged by slow-onset disturbances such as the loss of social capital. Nevertheless, the farm resilience is strong and oppose the ongoing structural change in agriculture (Stotten and Leitinger, 2018).
\end{abstract}
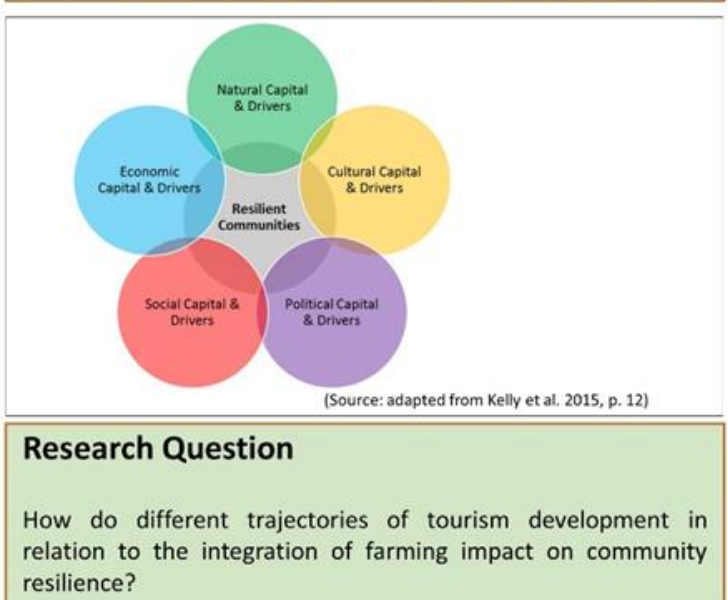

How do different trajectories of tourism development in relation to the integration of farming impact on community resilience?

\section{Tools and Methods}

The investigation is based on a qualitative research approach. In total, twenty expert interviews have been conducted with regional, municipal and local, male and female experts which are persons with specific knowledge in their particular fields of activity and with the function to be a representative of their peer group (Bogner and Manz 2002). Interviews have been verbatim transcribed and the content-analytical evaluation of the interviews was realized according to Mayring (2014).

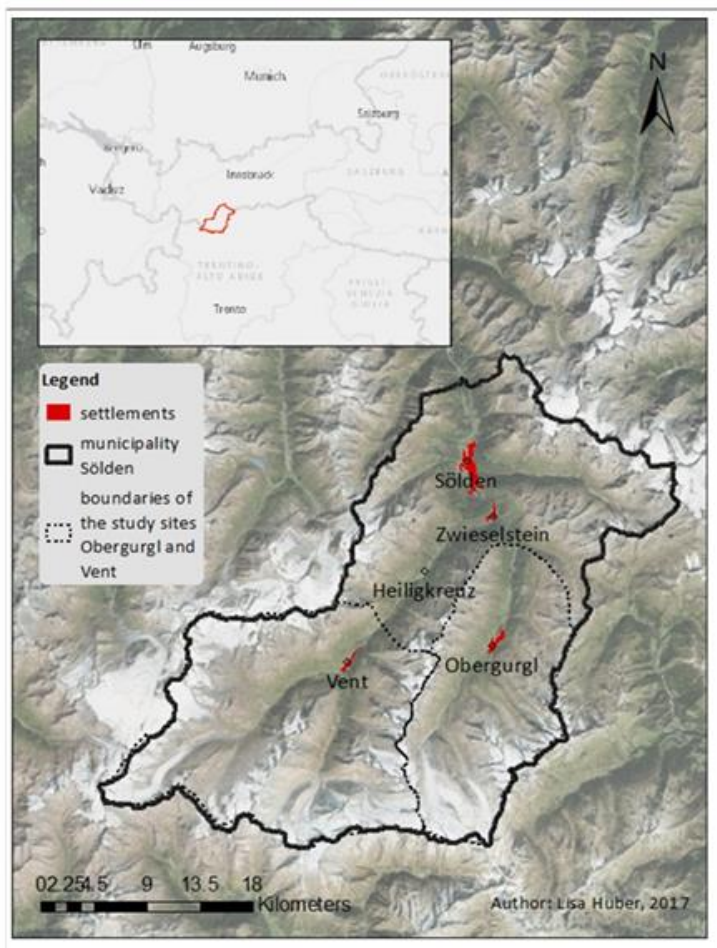

Results

The study highlights that both communities are facing substantial resilience challenges, however their vulnerability issues differ. On the one hand, Obergurgl is relying on its economic capital and drivers; its social capital (the cohesion of the community) has weakened with the structural change from a farming towards a service economy. Even if the remaining family farms are relatively resilient, their reputation within the community has lost dramatically. On the other hand, Vent is relying on its natural resources, valorizing its remote location and the agrarian landscape (Wilson, Schermer, and Stotten 2018). The case studies under investigation demonstrate two different trajectories and different configurations of capitals to aim for resilience. Further, it demonstrates that an approach based on the five resilience capitals and drivers provides a richly textured framework for understanding the subtleties of resilience pathways and transitions. 

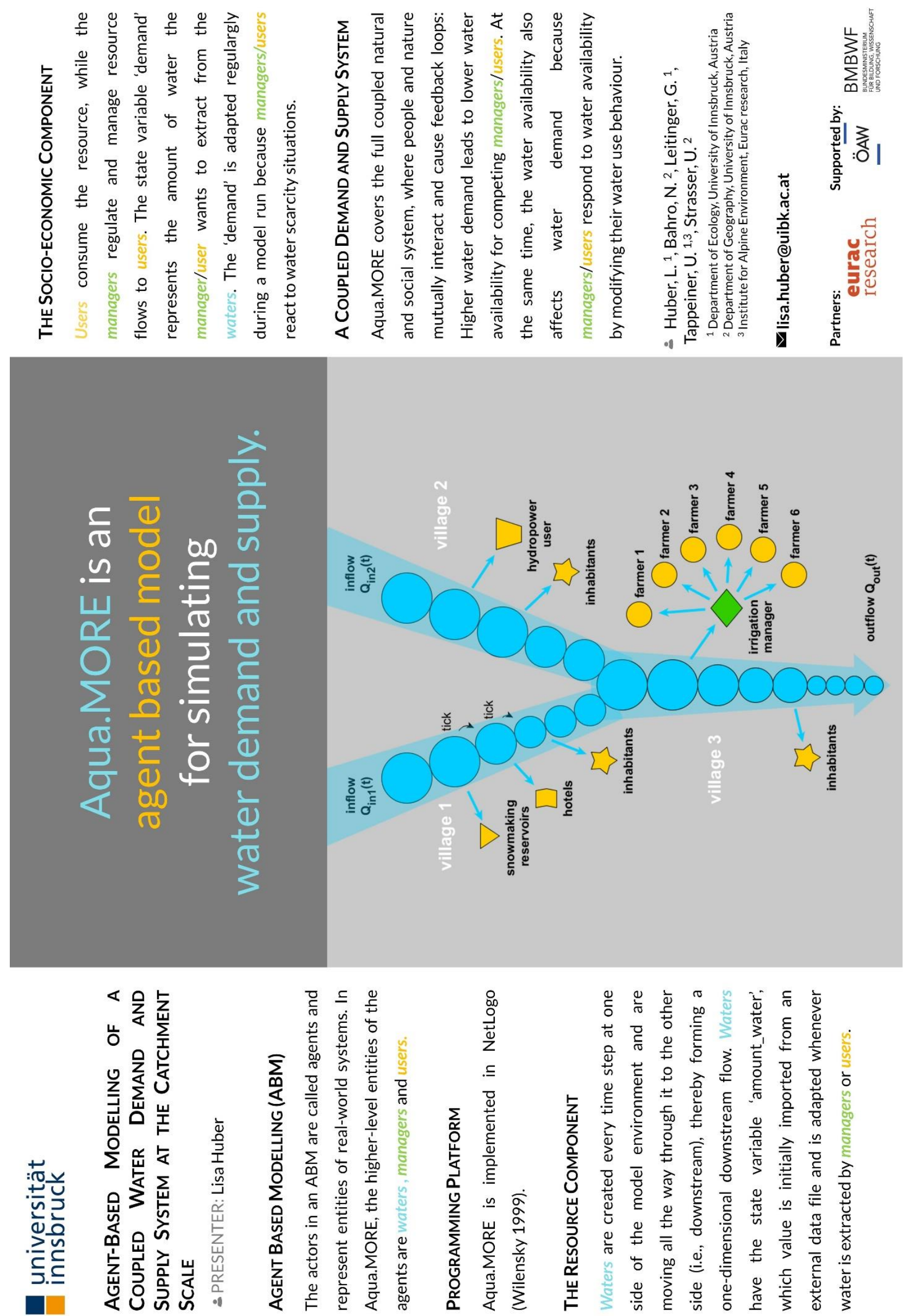


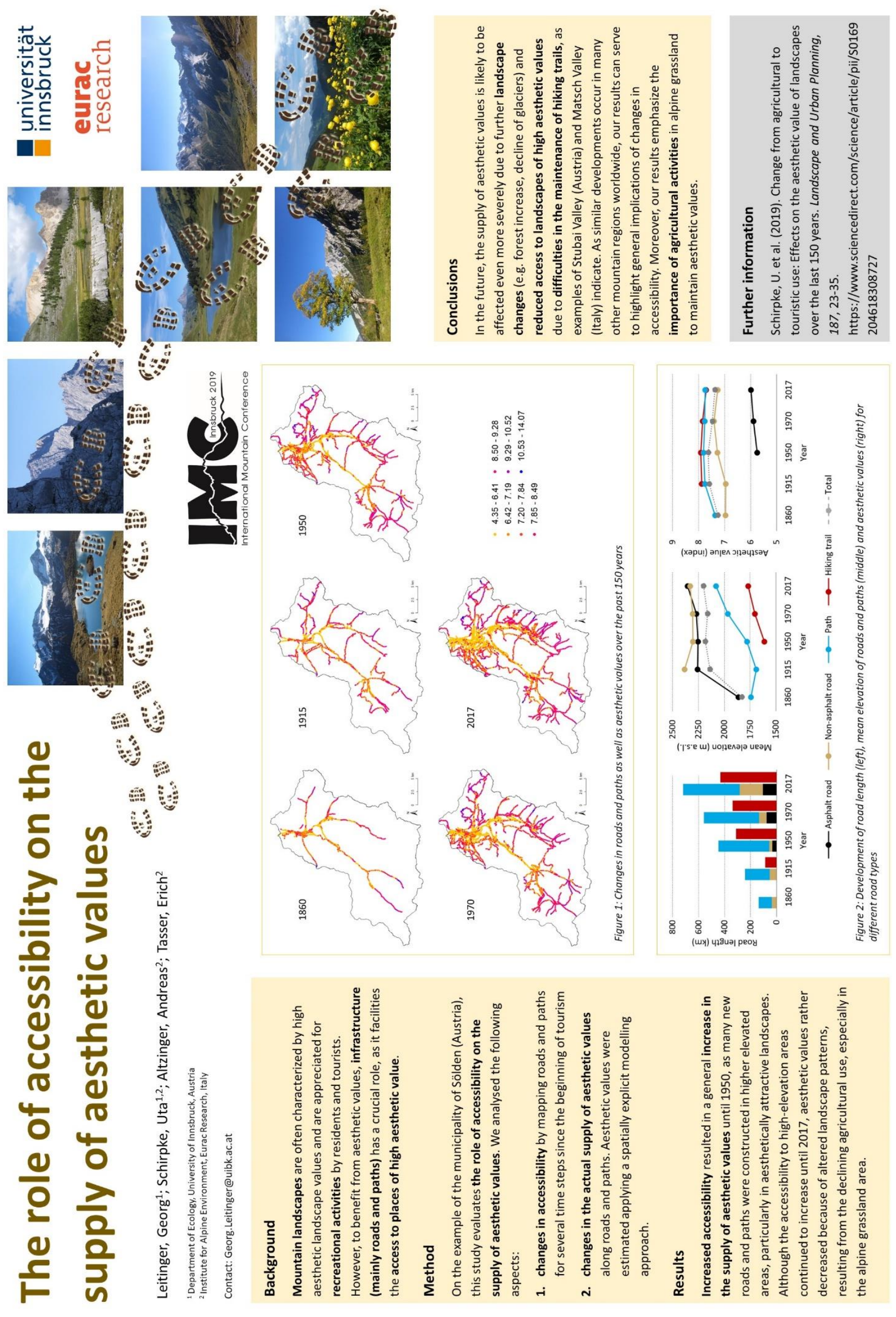




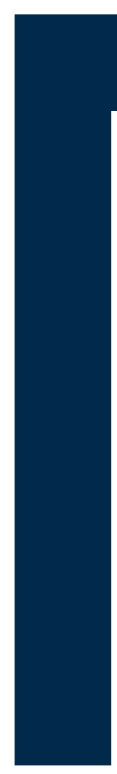

\section{IMPRESSUM:}

Department of Sociology

Working Group Rural Sociology

University of Innsbruck

Design: Research Center Tourism and Recreation

\section{CONTACT:}

Ass. Prof. Dr. Rike Stotten

Universitätsstraße 15

Universität Innsbruck

6020 Innsbruck

T +43512507 73425

rike.stotten@uibk.ac.at 